\title{
Employee Orientation and Financial Performance of Foundation Owned Firms
}

\author{
Matthias Draheim ${ }^{1}$ Günter Franke ${ }^{1}$ (D)
}

\begin{abstract}
Shleifer and Vishny (1997) argue that corporate governance should be weak in the absence of powerful residual claimants. We compare foundation owned firms (FoFs) and family firms, with and without codetermination. As foundations have no owners, residual claimants of FoFs are weak. This might strengthen FoFmanagers and employees. Codetermination law also strengthens employees. We derive hypotheses about business policy of FoFs and test them. Our findings show that German FoFs are more labor intensive relative to family firms. But their wages and their hiring and firing policy are about the same. Their financing policy is more conservative, their financial performance is slightly weaker. Apart from financing policy, codetermination has similar effects. These findings indicate a stronger impact on corporate governance of employees in firms with weak residual claimants and in codetermined firms, combined with long-term orientation. But, in contrast to Shleifer and Vishny (1997), we do not find evidence of weak corporate governance.
\end{abstract}

Keywords Stakeholder approach · Foundation owned firms · Codetermination · Privileged employee orientation · Financial performance

Both the legal protection of investors and some form of concentrated ownership (matching significant control rights with significant cash flow rights) are essential elements of a good corporate governance system (Shleifer and Vishny)

M. Draheim

matthias.draheim@axa-winterthur.com

$\triangle$ G. Franke

guenter.franke@uni-konstanz.de

1 Department of Economics, University of Konstanz, 78457 Konstanz, Germany 
JEL Classification Codes D22 · D24 · G32 · G35 - L21

\section{A Challenge to Corporate Governance Theory}

In their seminal survey Shleifer and Vishny (1997) summarize worldwide evidence of successful and failed corporate governance systems. They attribute failures largely to weak legal systems and to the separation of ownership and control. Large investors with significant cash flow rights in a firm have strong incentives to enforce these rights. If they also have strong control rights, then, given effective protection by law, they will effectively put pressure on the managers of the firm to manage it in their interest.

This conclusion appears to be incompatible with observations of successful firms in Europe which are owned by foundations. Well known examples of successful foundation owned firms (FoFs) are some big companies in Europe, in particular in Germany and Denmark. Big FoFs such as Bosch, ZF Friedrichshafen, Körber and Bertelsmann are located in Germany, Maersk and Tuborg are among the big FoFs in Denmark ${ }^{1}$.

Consider a firm which is fully owned by a charitable foundation. A foundation has no owners. It may have all control rights and all cash flow rights in the firm, but it has to spend the money, paid out by the firm, on charitable projects as stated in the foundation charter. The beneficiaries of these projects have no control rights. These may be exercised by the managers of the foundation. As they cannot use the money paid out by the firm for their private benefit, there exists a strict separation of ownership and control (Fama and Jensen 1983). Therefore it is unlikely that FoFs behave like firms with little separation of ownership and control. Instead FoFs may rely on a stakeholder approach as stated in laws which oblige managers to act in the "best interest of the company". The lack of cash flow rights of the foundation managers raises the question which objectives they pursue (see also Jensen 1986; Tirole 2001; Heath 2014). Do they understand their role as trustees of the founder and act in his spirit to assure the long term-existence of the foundation and the FoF? Or do they use their control rights to provide benefits to their friends and themselves? Or do they neglect their supervisory duties for their own convenience? Does such behavior weaken corporate governance of FoFs as argued by Shleifer and Vishny? Henceforth we use CG for corporate governance and S \& V for Shleifer and Vishny.

The purpose of this paper is to promote answers to these questions by analyzing the policy and the financial performance of German FoFs relative to German family firms. The latter provide a suitable benchmark for various reasons. First, most FoFs were family firms before the setup of the foundation. Hence, we study effects of this event. Second, in 2015, $91 \%$ of non-financial German firms and $45 \%$ of listed corporations were family-controlled (Stiftung Familienunternehmen 2017; see also Franks and Mayer 1997). As in a non-FoF with strong blockholders the (ultimate)

1 In Sweden IKEA and other firms owned by the Wallenberg Foundation are FoFs. FoFs also exist in the US, but foundation ownership is usually less than $20 \%$ to preserve tax privileges for charitable foundations. 
owners have the control rights and the cash flow rights and $\mathrm{S} \& \mathrm{~V}$ view legal protection in Germany as effective, they likely attribute good CG to German family firms. We compare these firms to FoFs in which CG might be impaired by a lack of powerful investors with cash flow rights. For analogy, state-owned firms are managed by bureaucrats who may pursue objectives like strengthening their political power, promoting their reelection or other perquisites (Villalonga 2000). Boycko et al. (1995) conclude from their empirical evidence that these firms are managed very badly, wasting a lot of resources with a drain of public funds.

A priori, it is not obvious whether CG is different in FoFs and non-FoFs. As a theoretical basis, we use stakeholder theory (Magill et al. 2015). Given various stakeholders with divergent interests, CG has to deal with conflicts of interests (Mayer 2013). Many firms in Continental Europe are family firms whose owners appear to pay voluntarily more attention to the interests of other stakeholders, in particular employees (Bau and Chirico 2014; Bingham et al. 2011). In FoFs residual claimants are weakened so that other stakeholders may be more powerful. We hypothesize that informally employees are more powerful in FoFs than in family firms. The power of employees is strengthened in Germany also by the codetermination law which assigns $1 / 3(1 / 2)$ of the seats of the supervisory board to representatives of the employees if the firm has more than 500 (2000) employees. We use this unique setting in Germany and also analyze codetermined firms to check whether foundation ownership and codetermination have similar effects on corporate policy. This provides an additional test of the role of more powerful employees in firms.

The null-hypothesis states that there is no difference in the policy and financial performance of FoFs relative to family firms. This hypothesis would be supported by perfect competition in the firm's product markets (Alchian 1950; Fama 1980) so that firms can only survive in the long run if they are managed effectively. Alternatively, the null-hypothesis can be motivated by side payments between different stakeholders for effective management in the sense of the Coase-Theorem (Coase 1960; Grossman and Hart 1986). But neither are product markets perfectly competitive nor are side payments between stakeholders frequently observed. It is also possible that foundation managers act in the spirit of the founder who may stipulate in the foundation charter that the FoF should be managed in the same way as the family firm before the setup of the foundation. This would also support the nullhypothesis. But, given the lack of cash flow rights of the foundation managers, their role is dubious.

An alternative hypothesis states that, relative to family firms, FoFs waste resources, similar to state-owned firms, indicating weak governance. Our empirical analysis of German FoFs, based on annual statements of the years 2003-2012, does not support weak CG in FoFs relative to family firms. Employees appear to be more powerful in FoFs, but the financial performance of FoFs is only slightly weaker than that of family firms. Thus, our findings challenge a mainstream of the CG literature.

Our novel contributions are as follows. First, given weaker residual claimants in FoFs, we hypothesize that managers and/or employees are more powerful stakeholders and promote their interests more effectively. We find that production in FoFs is more labor-intensive than in matching firms. Codetermination reinforces this effect. Labor intensity is raised by producing more labor-intensive products and services 
and/or by substituting labor for material. But we find a higher average income of managers or employees neither in FoFs nor in codetermined firms relative to matching firms. We also do not find significant differences in the annual hiring and firing policy between FoFs, codetermined firms and matching firms. However, employees in FoFs are better protected against layoffs in takeovers as foundations usually are not allowed to sell their ownership stakes. Thus, solvent FoFs cannot be taken over. Overall, these findings support a stronger employee orientation in FoFs and codetermined firms, relative to matching firms. We call this "privileged employee orientation". Second, a conservative corporate financing policy mitigates corporate vulnerability to negative shocks and, thus, helps to protect jobs of managers and employees. We find that leverage and profit payouts are lower in FoFs relative to matching firms. Codetermination, however, has no significant effect on financing policy in our sample. This is in contrast to Fauver and Fuerst (2006) who find a higher leverage and a higher probability of dividend payments in codetermined corporations.

Third, the theory of CG should relate variations in business policy, driven by variations in the stakeholder approach, to variations in financial performance. If privileged employee orientation is costly, then it should lower financial performance. This is measured by the average return on assets (RoA) and risk, proxied by the standard deviation $\sigma(\mathrm{RoA})$. In a panel data analysis we find that the average RoA is lower in FoFs when we linearly control for risk. Since codetermination has a similar effect on RoA as foundation ownership, FoFs likely attach more importance to employee interests. This conjecture is also supported by the observation that both, foundationownership and codetermination, lower business risk to a similar extent. We also measure financial performance of each firm by a Sharpe ratio, dividing the average (RoA minus risk-free rate) by $\sigma$ (RoA). This ratio is neither significantly affected by foundation ownership nor by codetermination, controlling for other factors. This finding contrasts with the negative performance effects found in the panel analysis. We conclude that foundation ownership and codetermination weaken financial performance, but this effect is small.

Fourth, joint ownership of a foundation and other owners appears to improve financial performance. Surprisingly, listing at a stock exchange weakens financial performance. But positive interaction between listing and foundation ownership eliminates both negative effects. Apparently "capital market control" eliminates some weaknesses of foundation ownership in $\mathrm{CG}$, and vice versa.

These findings are important for the theory of CG as they highlight the effects on business policy and financial performance of certain variations in the stakeholder approach. The effects of foundation ownership are similar to those of codetermination, except for financing policy. Hence, foundations likely put or tolerate a higher weight on employee interests, slightly weakening financial performance. Employees apparently do not maximise their benefits over the short/medium term by extracting higher income from the firm. Instead they pursue a long term-policy of safeguarding the existence of the firm, thereby promoting long term-job security without constraining the firm's short term-flexibility of hiring and firing. Also a conservative financing policy supports the stability of the firm. In contrast to the scepticism of $\mathrm{S} \& \mathrm{~V}$, the observed privileged employee orientation does not promote an "aggressive" package 
of employee benefits with strong adverse effects on the firms' financial performance and competitivity, but a "conservative" package of employee benefits with weak effects on financial performance so that long term-competitivity is not endangered.

Our results do not indicate weak CG of FoFs relative to family firms. While $\mathrm{S} \& \mathrm{~V}$ measure the quality of a firm's CG by its ability to attract external funds, we use a broader measure derived from the stakeholder model. In this model, the efficient frontier portrays the utilities of the different stakeholder groups for the set of Pareto-optimal business policies. We define good CG as operating on the efficient frontier, subject to the condition that the long-term existence of the firm is not endangered. As privileged employee orientation is costly, but effects on financial performance are only weak, our results do not indicate weak CG of FoFs relative to family firms. These findings suggest that, in contrast to S \& V, the lack of strong residual claimants need not weaken CG. Thus, our findings challenge a mainstream of the CG literature.

At least two channels may explain why the separation of ownership and control associated with foundation ownership and codetermination has only small effects on financial performance of FoFs. Foundation managers may perceive their role as fiduciaries on behalf of the founder so that they act in his spirit to preserve the long run-existence of the firm and their reputation as supervisors. Thus, they may put pressure on the FoF-managers to safeguard profitability. Alternatively, managers and employees of the FoF themselves pursue profitability to preserve their jobs in the long run so that guidance of foundation managers may be largely irrelevant.

Our conclusion that foundation ownership weakens financial performance contrasts with earlier studies. Thomsen (1996) investigates book returns of Danish FoFs. Consistent with the null-hypothesis, he does not find inferior returns relative to the largest Danish non-FoFs. Thomsen and Rose (2004) compare Danish FoFs to other Danish firms listed at a stock exchange while Thomsen and Hansmann (2013) compare them to firms with a traditional ownership structure. Both studies also use stock market data and arrive at the same conclusion as Thomsen (1996) ${ }^{2}$. In an early study Herrmann (1996) and Herrmann and Franke (2002) analyze a small sample of German FoFs over the short period of 1990-1992. Relative to German firms listed at a stock exchange, they find slightly higher returns on assets, higher labor intensity, but lower salary levels in FoFs. Risk is ignored.

The paper is organized as follows. The next section provides details about motives of founders and the regulation of foundations in Germany. Then we derive hypotheses on corporate policies and performance of FoFs. The subsequent section presents descriptive statistics and our empirical findings. After discussing robustness results the paper concludes.

${ }^{2}$ Hansmann and Thomsen (2013) find that greater managerial distance between the foundation board and the FoF board raises the return on assets. 


\section{Background of Foundation Owned Firms}

Usually the founder is a successful entrepreneur who transforms his family firm into a FoF to assure that the firm thrives "forever". Therefore, CG of the FoF likely inherits features of the family firm. The foundation gets an ownership stake in the firm which usually cannot be sold. In Germany motives of founders differ with regard to the beneficiaries of the foundation (Götz and Pach-Hanssenheimb 2016). Founders of a charitable foundation wish to fund charitable activities. Its beneficiaries have no control rights in the foundation. Charitable foundations are tax-exempt. Founders of a family foundation may be afraid of conflicts between family members which may endanger the stability of the family firm. The family foundation provides limited control rights and restricted financial support to family members. They cannot sell their claims against the foundation. It is not tax-exempt.

Another motive for setting up a foundation is regulatory arbitrage. A family firm may be a partnership in which at least one partner has unlimited liability. A foundation can take the position of the unlimited liability partner and remove full liability of natural persons. As a fully liable partner, the foundation is entitled to manage the firm. In our sample, 14 family foundations are fully liable partners, but mostly have no equity stake, i.e., no claim on the firm's profit. They get a fixed fee for management and taking the unlimited liability-risk.

Another type of regulatory arbitrage relates to the German codetermination law. To avoid codetermination, Aldi and Lidl, two very big retail store chains, set up various small regional partnerships which own the supermarkets. These partnerships are owned by family foundations, similar to holding companies.

Regulation of foundations is mostly governed by the German federal state in which the foundation is domiciled. Setting up a foundation requires the founder to design a foundation charter specifying the purpose of the foundation, its activities, and how the foundation should be managed. It may also contain rules about CG of the FoF. The charter is an important and effective device for the founder to impose his will "forever" on the foundation and the FoF. The charter is very difficult to change once it has been approved by the state. The state does not interfere in the foundation's policies as long as the charter is observed. Even though the foundation managers are obliged to act according to the charter, outside control can be weak leaving much discretion to them. This may be a problem even more since retiring foundation managers are usually replaced by cooptation of the foundation board, without outside control. Large foundations usually publish annual reports, in contrast to small foundations. By law, foundations should preserve their capital, defined in real terms. Hence, foundations are obliged to adopt a long-term orientation.

As most FoFs originate from family/closely held firms and most matching firms in our sample are of this type, we briefly characterize these. The role of owners in a family/closely held firm is controversial. Owners with a relational/stewardship attitude adopt a stakeholder orientation, while owners with an individualistic attitude maximize their private benefits (Jones et al. 2007; Kallifatides et al. 2010, Ch. 1 and 22). Empirically, Bau and Chirico (2014) and Bingham et al. (2011) find a relational attitude in family firms which benefits employees (also Hillman and Keim 2001). Van Essen et al. (2015) find that family controlled firms less likely downsized 
their workforce or cut wages during the last financial crisis. An important reason for this kind of stakeholder culture in closely held firms could be the long-term presence of the owner-managers (Anderson and Reeb 2003). In these firms the same ownermanagers are dealing with other stakeholders for longer periods than in public firms, promoting stronger ties. While family firms may suffer from tensions in the family and excessive valuation of socio-emotional wealth, they may avoid separation of ownership and control and promote long-term oriented corporate policies. Bezemer et al. (2015) argue that a stakeholder culture prevails in the Netherlands. This is also true of Germany. Donaldson and Preston (1995) argue that a stakeholder culture is widely observed even in the US.

\section{Theory and Hypotheses}

\subsection{A Stylized Stakeholder Model}

The theory of CG should answer the following questions. Does a lack of powerful residual claimants in FoFs weaken CG? How is this vacuum of power filled? Do firm managers and employees informally strengthen their power and benefits? What are the implications for the firm's policy and financial performance? What are the effects of mixed ownership structures with foundations and traditional residual claimants as owners? What happens if $\mathrm{CG}$ is also affected by codetermination? We address these stakeholder approach-variations by deriving and testing hypotheses.

The stakeholder model (Magill et al. 2015) serves as a theoretical basis even though this model is often criticized for its ambiguities, e. g. by Heath (2014). Three reasons motivate the stakeholder approach. First, as argued before, a stakeholder approach broader than the shareholder value approach appears to prevail in Continental Europe. Second, according to the German Corporate Law (§ 93 (1)) managers carry out their duties if they "act in the interest of the company". This interest is not confined to its shareholders. Third, we analyze the effects of transforming family firms into FoFs and the effects of codetermination. These effects are modelled by changing the weights of certain stakeholder groups in the stakeholder model. In the stakeholder model of Magill et al. (2015) $\mathrm{u}_{\mathrm{i}}(A)$ denotes the utility of stakeholder (group) $i$ given the firm's policy $A$. A linearly calibrated stakeholder model attaches the nonnegative weight $\lambda_{\mathrm{i}}$ to stakeholder $i$. The optimal policy $A^{*}$ of the firm is the solution to:

$$
\max _{A} \sum_{\mathrm{i}} \lambda_{\mathrm{i}} \mathrm{u}_{\mathrm{i}}(A) \quad \text { s.t. } \quad \mathrm{u}_{\mathrm{i}}(A) \geq 0 \text { for each i; } A \varepsilon \Phi, \quad \sum_{\mathrm{i}} \lambda_{\mathrm{i}}=1 .
$$

$\mathrm{u}_{\mathrm{i}}(A) \geq 0$ is the participation constraint of stakeholder $i$. $\Phi$ denotes the set of feasible firm policies, defined by institutional and other constraints. The stakeholder weights add up to 1 . The optimal policy $A^{*}$ depends on the weights, $A^{*}=A^{*}\left(\lambda_{\mathrm{I}}\right)$ with $\lambda_{\mathrm{I}}=\left(\lambda_{1}\right.$, $\left.\lambda_{2}, \lambda_{3}, \ldots\right)$. The set of optimal policies derived from the set of all feasible weight vectors yields the efficient frontier of the model. This frontier displays the utilities of all stakeholders for the set of optimal policies. Transforming a family firm into 
a FoF (partially) replaces owners with cash flow and control rights by a foundation so that their weight should decline and that of the foundation managers becomes positive. This transformation should induce a move on the efficient frontier. As a consequence, the utility of residual claimants proxied by financial performance should decline while the utility of other stakeholders might increase.

The stakeholder model motivates a broader definition of good CG than the shareholder value model which, as a special variant of the stakeholder model, attaches weight 1 to residual claimants. While these may measure the quality of CG by the firm's ability to attract outside capital as suggested by S \& V, the stakeholder model attests good CG to a firm if it operates on the efficient frontier, subject to the condition that the long term-existence of the firm is not endangered. CG is weaker, the more resources are wasted, i.e. the more the stakeholders' actual utilities are below the frontier. We use this definition of CG. The condition of long term-existence of the firm is motivated in particular for FoFs by the founders' will.

Which stakeholders benefit from higher stakeholder weights after the transformation to a FoF? Kochan and Rubinstein (2000, p. 373) suggest three conditions for stakeholders "to gain sufficient influence to challenge the centrality of finance capital" for the firm. (1) These stakeholders "need to supply critical resources or assets" to the firm. (2) "The value of their assets must be affected by the fate" of the firm. (3) "They need to amass sufficient power". Applying these criteria, FoF-managers are in an excellent position to absorb power released by residual claimants. Moreover, they have the privilege to take important managerial decisions and they are the only group of stakeholders with contractual relationships to all other stakeholders (Hill and Jones 1992). Similarly, the group of other employees may gain power because they also fit the conditions of Kochan and Rubinstein well. This is obvious for the first two conditions, it also holds for the third. As argued by Rajan and Zingales (1998), access is critical for the allocation of power. Employees have excellent access to managers because they are always present in the firm, their representatives often talk to managers, informally and formally in the workers' councils, established by German law.

The managers of the foundation, a new stakeholder group, are assigned some power by law as they supervise the FoF. They may amass power if the foundation is a blockholder and if they use their control rights effectively (Shleifer and Vishny 1997). But they do not satisfy the first two conditions. Therefore their influence as a new stakeholder group is presumably weaker than that of residual claimants. Ideally speaking, the foundation managers should act in the spirit of the (deceased) founder, take a fiduciary role and "execute" his will. But, given weak control, they may pursue their own objectives. Agency theory may help to develop contractual arrangements to harmonize the interests of the foundation managers and the founder (Holmström 1979; Eisenhardt 1989).

Other groups of stakeholders [creditors, suppliers, customers, environmentalists] may also gain power in FoFs, but they appear to be in a less favored position than managers and employees. Moreover, employees and their subset "managers" partly share joint interests. Hence, more power may induce managers to also promote these interests. However, if FoF-managers want to constrain claims of other stakeholders 
such as employees, they may ask foundation managers for support (Van Essen et al. 2013).

Hence, we conjecture that primarily managers and employees gain power when residual claimants are (partially) replaced by foundation managers. If FoFs attach a higher weight to employee interests relative to family firms, we call this "privileged employee orientation". Therefore most of our hypotheses compare corporate policies and financial performance of firms with a privileged employee orientation to those of family firms.

The codetermination law formally strengthens employees in every large firm. Hence, codetermination and foundation ownership might have similar effects on business policy. If this turns out to be true, then this confirms privileged employee orientation in FoFs. Jensen and Meckling (1979) argue that codetermination constrains firms and, thus, is inefficient; this may explain why codetermination has not been adopted in countries other than Germany. Other authors take a more positive view. Hall and Soskice (2001, Introduction) present a relational view of the firm. For them the quality of the relationships between stakeholders within a firm is critical. Employees collect information about the firm that can be valuable to management, but they can also withhold information and reduce their efforts. Gorton and Schmid (2004) find that companies with equal representation of employees and shareholders on the supervisory board trade at a substantial stock market discount relative to companies with one third representation of employees. Fauver and Fuerst (2006), however, find that Tobin's Q significantly improves with employee representation for firms in industries that demand strong coordination with workers. Labor representation may improve monitoring and reduce managerial agency costs. Jirjahn (2011) reviews the controversial empirical findings about effects of workers' councils and codetermination. In the following, we first derive hypotheses on employment and production policy and then on financing policy and financial performance.

\subsection{Privileged Employee Orientation}

\subsubsection{Employment and Production Policy}

As argued before, foundation ownership might lead to privileged employee orientation in FoFs relative to family firms. This orientation should also be supported by codetermination. Privileged employee orientation can take many forms. For example, working conditions including working hours, working climate and family friendliness might be improved, coaching and training of employees might be intensified (see the survey of Jirjahn 2011). While these improvements may motivate employees intrinsically, extrinsic motivation may be strengthened by higher labor income (Rebitzer and Taylor 2011). We start from the observation that wage increases and job security usually play the most important role in the regular negotiations between German trade unions and employer associations. Therefore we focus on these two topics. Higher wages illustrate the concern of $\mathrm{S} \& \mathrm{~V}$ that less powerful residual claimants allow other stakeholders to extract rents, perhaps wasting money. The conflict between higher wages and job security is obvious. If a FoF pays higher wages than required by collective labor agreements, then this endangers the FoF's 
competitivity and, thus, long term-job security. Essential is whether employees pursue a short- or long-term perspective in the firm. In his analysis of the labor-managed firm Furubotn (1971) argues that the employees' time horizon depends, apart from their age, on their options to extract money from the firm in the short/medium-term and on their outside opportunities to earn money. If it is difficult for employees to find another job, then they may attach a high value to job security. This is even more important in the case of firm-specific human capital of employees which cannot be transferred to other jobs (Jensen and Meckling 1979). Therefore, the employees' time horizon regarding their job depends on various factors.

If the FoF pays its employees substantially higher labor income and guarantees jobs for substantially longer time periods than family firms, then this indicates an aggressive package of privileged employee orientation. This might endanger the long term existence of the firm and illustrate the agency-driven skepticism of S \& V. In contrast, a conservative package would benefit employees in some aspects, but preserve the firm's long term-competitivity, thus effectively mitigating the concerns of S \& V and perhaps be compatible with good CG. For example, employees might not earn an extra pay, but the FoF might support long term-job security. Hypothesis 1 presents an aggressive package of privileged employee orientation in employment and production policy.

Hypothesis 1 Privileged employee orientation (a) raises the average income of employees and strengthens job security by (b) raising the number of jobs, (c) curtailing hiring and firing.

We briefly discuss strategies to raise the number of jobs ${ }^{3}$. (i) The firm can offer more (product-related) services and produce more labor intensive products. Also it may substitute (ii) labor for capital by using less technical equipment or (iii) labor for material by producing material internally instead of buying it. These strategies raise the number of jobs and may also strengthen job security in the long run without endangering the firm's competitivity.

To check for labor intensity of the firm, we analyze accounting items and ratios. All three strategies should raise the firm's ratio "Personnel expense / operating revenue". (i) Concentrating on labor intensive products and services may have little impact on depreciation and material expense. (ii) Substituting labor for capital raises the ratio "Personnel expense / depreciation". (iii) Substituting labor for material raises "Personnel expense / material expense" and lowers "Material expense / operating revenue" if operating revenue does not change. If, however, the substitution is achieved by vertical integration of firms, then consolidation in the annual statement lowers the operating revenue of the merged firm. This should reinforce the increase in "Personnel expense / operating revenue". Hence, a high ratio "Personnel expense / operating revenue" may not be driven by low labor productivity. "Material

\footnotetext{
3 Instead of raising the number of jobs existing employees might prefer to maximize benefits per employee. That might prohibit new jobs. But firms need to hire young people to balance the age pyramid of employees and to expand when there are new windows of opportunity.
} 
expense / operating revenue" of the merged firm should be lower than the average of the ratios of the non-merged firms, weighted by their operating revenues ${ }^{4}$.

Similar results may be obtained from analyzing the firm's long-term production function. For simplicity, we approximate the firm's production function by a CobbDouglas function:

$$
\ln \mathrm{OR}=\alpha \ln \mathrm{PE}+\beta \ln \mathrm{ME}+\gamma \ln \mathrm{DE}+\delta \ln \mathrm{OE}
$$

with:

$\mathrm{OR}=$ operating revenue

$\mathrm{PE}=$ personnel expense

$\mathrm{ME}=$ material expense

$\mathrm{DE}=$ depreciation

$\mathrm{OE}=$ other production expenses.

$\alpha, \beta, \gamma$, and $\delta$ are the elasticities of the operating revenue with respect to the production factors. These elasticities should add to $1, \alpha+\beta+\gamma+\delta=1$.

To model the impact of privileged employee orientation, we use a simplified version of Eq. 1 and assume that the firm maximizes a weighted average of operating revenue and personnel expense, $\kappa \mathrm{OR}+(1-\kappa) \mathrm{PE}, 0<\kappa<1$. The weight $(1-\kappa)$, attached to personnel expense, is higher under privileged employee orientation. The objective function is maximized with respect to $\mathrm{PE}, \mathrm{ME}, \mathrm{DE}$, and $\mathrm{OE}$, subject to the budget constraint $\mathrm{PE}+\mathrm{ME}+\mathrm{DE}+\mathrm{OC}=\mathrm{TC}$. Assume the total production cost TC to be given. Then a higher weight of personnel expense lowers the optimal operating revenue and raises the optimal personnel expense and the elasticity of operating revenue with respect to personnel expense, indicating higher labor intensity. The expenses for the other production factors and their corresponding elasticities decline. This follows from the optimization as shown in an appendix (electronic supplementary material). If operating revenue strongly declines, then this might impair the firm's ability to attract external funds, in line with concerns of S \& V. The optimization results motivate Hypothesis 2 which is closely related to Hypothesis $1 \mathrm{~b}$.

Hypothesis 2 Privileged employee orientation raises the elasticity of operating revenue with respect to personnel expense and the ratio "Personnel expense / operating revenue"; it lowers the elasticity of operating revenue with respect to material expense and the ratio "Material expense / operating revenue".

\footnotetext{
${ }^{4}$ For illustration, merge two firms with subsequent production stages. Before the merger, each firm has its own material expense and its own operating revenue. As an approximation, the operating revenue of the firm with the first production stage equals the material expense of the firm with the second production stage. In the "consolidated annual statement" the material expense of the second firm is netted against the operating revenue of the first firm while personnel expenses are added. It can be shown that "Personnel expense / operating revenue" of the integrated firm is higher than the average of the ratios of the two firms, weighted by their operating revenues. "Material expense / operating revenue" of the integrated firm is smaller.
} 
(iv) Job security also relates to the diversity of the firm's product portfolio. Many firms streamline their product portfolio by focusing on core competences. This leads to spin-offs and closures of product lines, the number of employees declines. Given privileged employee orientation, FoFs may abstain from such policies and promote internal firm growth. This might help to explain why FoFs are mostly larger than matching firms.

(v) In the short/medium term job security depends on the firm's hiring and firing policy. FoFs may react less aggressively in firing employees after a decline and rehiring after an increase in sales (Hypothesis 1c). They may use subsidized shorttime work or other working-flexibility arrangements or reduce production speed to protect jobs. The latter might be driven by weakness of residual claimants and impair financial performance, illustrating worries of $\mathrm{S} \& \mathrm{~V}$.

\subsubsection{Conservative Financing Policy}

Our next hypothesis claims that FoFs adopt a more conservative financing policy than family firms, i. e. they have lower leverage and distribute less profits. (1) A conservative financing policy benefits employees by strengthening the firm's financial stability and, thereby, long term-job security. Employees who extract higher wages might try to reduce payouts to the owners of the FoF so as to mitigate adverse effects on financial stability. (2) We conjecture that foundation managers push less for profit payouts than residual claimants who use these payouts for their personal benefit including outside investments ${ }^{5}$. (3) If the foundation managers want to preserve the long run existence of the firm, then they also support a more conservative financing policy. (4) Charitable foundations often have little financial reserves (to assure their preferential tax status) so that they can hardly supply new equity capital to FoFs. This severely restricts new equity issues of FoFs, making it more important to retain earnings and lower leverage in good times. (5) As argued by S \& V, profit payouts motivate owners to supply fresh equity capital when needed. This role is largely eliminated by foundation ownership so that profit payouts are less attractive for the FoF. (6) A conservative financing policy also benefits other stakeholder groups [creditors, suppliers, customers]. These stakeholders welcome lower default risk. If creditors are afraid of money extraction by employees, they may impose strong credit constraints to prevent such behavior. Given weak residual claimants and strong restrictions on fresh equity capital, creditors may insist on a conservative financing policy if loan-interest rates are to stay the same (see also Istaitieh and Rodriguez-Fernandez 2006) ${ }^{6}$. These considerations motivate:

Hypothesis 3 Foundation owned firms adopt a more conservative financing policy relative to family firms, i.e. they have lower leverage and pay out less profits.

\footnotetext{
5 Fast growing firms may retain all earnings to fund future growth.

6 Chen et al. (2012) find that firms with unionized workers (in which employee orientation is likely stronger) invest less risky and pay lower bond coupons than other firms. Croci et al. (2011) find that family firms (in which employee orientation tends to be stronger than in public firms) invest less risky and obtain more long-term debt (see also Lins et al. 2013).
} 
Residual claimants, however, may dislike a conservative financing policy because low leverage and low profit payouts may motivate a generous spending policy as stated by the free cash flow argument (Jensen 1986; Core et al. 2005). Thus, this policy may impair financial performance, supporting the scepticism of S \& V.

\subsubsection{Financial Performance}

All firms would grant costless benefits to employees, i.e. benefits which do not impair the utility of other stakeholders ${ }^{7}$. If codetermined firms and FoFs provide more benefits than other firms, these benefits likely are costly and weaken financial performance.

Hypothesis 4 Privileged employee orientation lowers financial performance. This effect is stronger, the more costly (aggressive) the package of employee benefits is.

This hypothesis illustrates the core of the worries of S \& V.

\subsubsection{Heterogeneity of Foundations}

Are the effects of privileged employee orientation the same for charitable and family foundations? The heterogeneity of foundations permits us to obtain additional insights into CG effects of different stakeholder approaches. If a charitable foundation is the single owner of a FoF, natural persons being residual claimants have no power so that privileges of employees may be extensive. In a family foundation the charter usually reserves some power for the family. As the family receives financial support from the foundation which is funded by the FoF, the family is a constrained residual claimant of the FoF. Thus, in line with S \& V, family members may constrain privileged employee orientation, in contrast to the beneficiaries of charitable foundations. Hence, we expect less privileged employee orientation in FoFs owned by family foundations.

Hypothesis 5 Employee orientation is weaker in firms owned by family foundations than in those owned by charitable foundations.

\section{Descriptive Statistics}

In our empirical analysis we compare German FoFs and German matching firms. First, we present descriptive statistics. In the subsequent econometric analysis, we also investigate the subsets of codetermined firms to check for similarities between FoFs and codetermined firms.

In 2007 Fleschutz published a list of 419 German FoFs. Marc Eulerich from the University of Duisburg/Essen recently updated this list which now includes 740 FoFs (Fleschutz 2007). He was kind enough to provide us his new list which

\footnotetext{
${ }^{7}$ Hillman and Keim (2001) find that firms improving their relations with employees often raise shareholder value. These cases illustrate a win-win situation.
} 
Table 1 Summary Statistics

\begin{tabular}{|c|c|c|c|c|c|}
\hline- & All FoFs & $\begin{array}{l}\text { Charity- } \\
\text { owned } \\
\text { FoFs } \\
\text { no/yes }\end{array}$ & $\begin{array}{l}\text { Full liabil- } \\
\text { ity-FoFs } \\
\text { no/yes }\end{array}$ & $\begin{array}{l}\text { Vote share } \\
<0.5>0.5\end{array}$ & $\begin{array}{l}\text { Equity share } \\
<0.5>0.5\end{array}$ \\
\hline \multirow[t]{2}{*}{ Number of firms } & 164 & $55 / 105$ & $150 / 14$ & $52 / 112$ & $80 / 84$ \\
\hline & \# of obs & Mean & Median & $25 \%$-quantile & $75 \%$-quantile \\
\hline \multicolumn{6}{|c|}{$\varnothing$ Total assets (mill EUR) } \\
\hline FoFs & 164 & 1070 & 80.8 & 20.9 & 458 \\
\hline Matching firms & 757 & 451 & 51.7 & 15.9 & 181 \\
\hline \multicolumn{6}{|c|}{$\varnothing$ Operating revenue (mill EUR) } \\
\hline FoFs & 151 & 1200 & 151 & 49.6 & 730 \\
\hline Matching firms & 531 & 532 & 109 & 33.6 & 311 \\
\hline \multicolumn{6}{|c|}{$\emptyset$ Number of Employees } \\
\hline FoFs & 164 & 5588 & 624 & 171 & 3156 \\
\hline Matching firms & 757 & 2050 & 320 & 106 & 1093 \\
\hline
\end{tabular}

Summary statistics for foundation owned firms (FoFs) and matching firms. All firms are for profit-firms. Charity-owned FoFs are FoFs with ownership by a charitable foundation, no-charity-owned FoFs are FoFs with ownership by a family foundation. Full liability-FoFs are FoFs with unlimited liability of the foundation. Vote share [equity share] is the foundation's share of voting rights [equity-cash flow rights] in the FoF. In the lower part of the table descriptive statistics for average total assets, average operating revenue, and average number of employees across firms are shown. For each firm an average number $(\varnothing)$ is a simple average of its numbers within the sampling period

appears to be very carefully derived. This list includes for-profit- and not for-profit firms, parent companies and subsidiaries. In this paper we only analyze for-profit firms. As only a small fraction of FoFs is listed, we only use accounting data. We include a firm of the Eulerich list in our sample only if several requirements are met. First, we exclude financial firms. As we obtain annual statements from the data base Orbis, we exclude firms for which Orbis does not provide (enough) reliable data. These are mostly small firms. As cutoff points, we require a minimum annual operating revenue of $380,000 €$ in the sampling period 2003-2012 and minimum total assets of 49,000€. Second, we only consider operating units as firms, i.e., legal entities with operating revenues generated within this entity. Such an entity may be a subsidiary of another firm.

Third, we include a firm as a FoF if (a) the foundation has limited liability in the firm and has at least $2 \%$ of the voting rights or $2 \%$ of the equity stake (i.e. equity-cash flow rights), or (b) if the foundation is an unlimited liability-partner. Often, shares of voting rights and of equity stakes differ substantially. We obtain the foundation's share of equity stakes from the German database Hoppenstedt and the share of voting rights from Orbis as far as possible. In addition, we hand-collect data from public registers. Since often pyramid structures of firms exist, we derive the effective shares of the foundation in the FoF (similar to Franks and Mayer 1997). As a lower limit for the foundation share we use $2 \%$ for two reasons. First, the wide range of $2-100 \%$ allows us to see the impact of the share more clearly in the regressions. Second, as foundations enjoy a very good reputation in Germany (Institut für Demoskopie 2012), even a small share may affect CG of the FoF. This 
leaves us with 164 for-profit FoFs. Even though the number of FoFs may increase slightly over time, our sample is representative for Germany.

We match each FoF with firms of the same industry and similar size, following other papers (e.g. Strebulaev and Yang 2013). Matching firms are also German and taken from Orbis. We use two digit US SIC codes for industry classification. But whenever there are more than 100,000 German firms in a two digit US SIC industry, we use the three digit US SIC codes for a finer classification. Size is measured by operating revenue or by total assets. Both are correlated with 0.945 . If possible, we select for each FoF five matching firms of the same industry which are closest in size. Our sample contains 757 matching firms. Hence, on average, for every FoF we use 4.6 matching firms. By using several matching firms, we try to neutralize idiosyncrasies of matching firms. The disadvantage of using many matching firms is that the average size difference between a FoF and its matching firms increases. Most matching firms are family/closely held firms (Stiftung Familienunternehmen 2017). As there are no matching firms for the big discount stores Aldi and Lidl, we exclude these FoFs.

Sometimes total assets and/or operating revenue of a firm change dramatically from one year to the next. This can be due to a merger, a split-off, (partial) liquidation or data errors. Whenever in a firm total assets, operating revenue, or the number of employees declines by more than $50 \%$ or increases by more than $100 \%$ from one year to the next, we only use the data starting after the dramatic change. Comparing different sets of firms can lead to reliable insights only if the firms exhibit some stability. We winsorize data at the $1 \%$ and at the $99 \%$-quantile. We deflate accounting numbers to the 2003-price level by the Eurostat BIP-deflator for Germany.

As shown in Table 1, the foundation is charitable in 105 cases, in 55 cases non-charitable (= family foundation). In 4 cases a charitable and a non-charitable foundation share ownership in a FoF. These cases are excluded when we analyze FoFs related to either a charitable or a non-charitable foundation. In 150 FoFs the foundation has limited liability, in 14 FoFs full liability so that it has all voting rights. The foundation has the majority of votes in 112, the majority of equity-cash flow rights in 84 cases.

To portray differences between FoFs and matching firms, we look at various accounting numbers. For each firm we use the time series of its numbers and take averages for descriptive statistics. The frequency distributions of these averages are strongly skewed to the right.

Size Total assets, operating revenue, and the number of employees tend to be clearly higher in FoFs relative to matching firms (lower part of Table 1). Only in "chemicals/rubber/plastics", "gas/electricity", and "other services" the median operating revenue of FoFs is lower than that of matching firms. Several reasons may explain the larger size of FoFs. Entrepreneurs are more likely to transform a successful firm into a FoF. Successful firms likely are larger. Hence, we expect a "birthbias" towards large FoFs. Moreover, if the entrepreneur has a strong employee orientation already before setting up a FoF, then the firm might employ more people. This would reinforce the "birth-bias". If the FoF continues this policy, then it should stay large. 


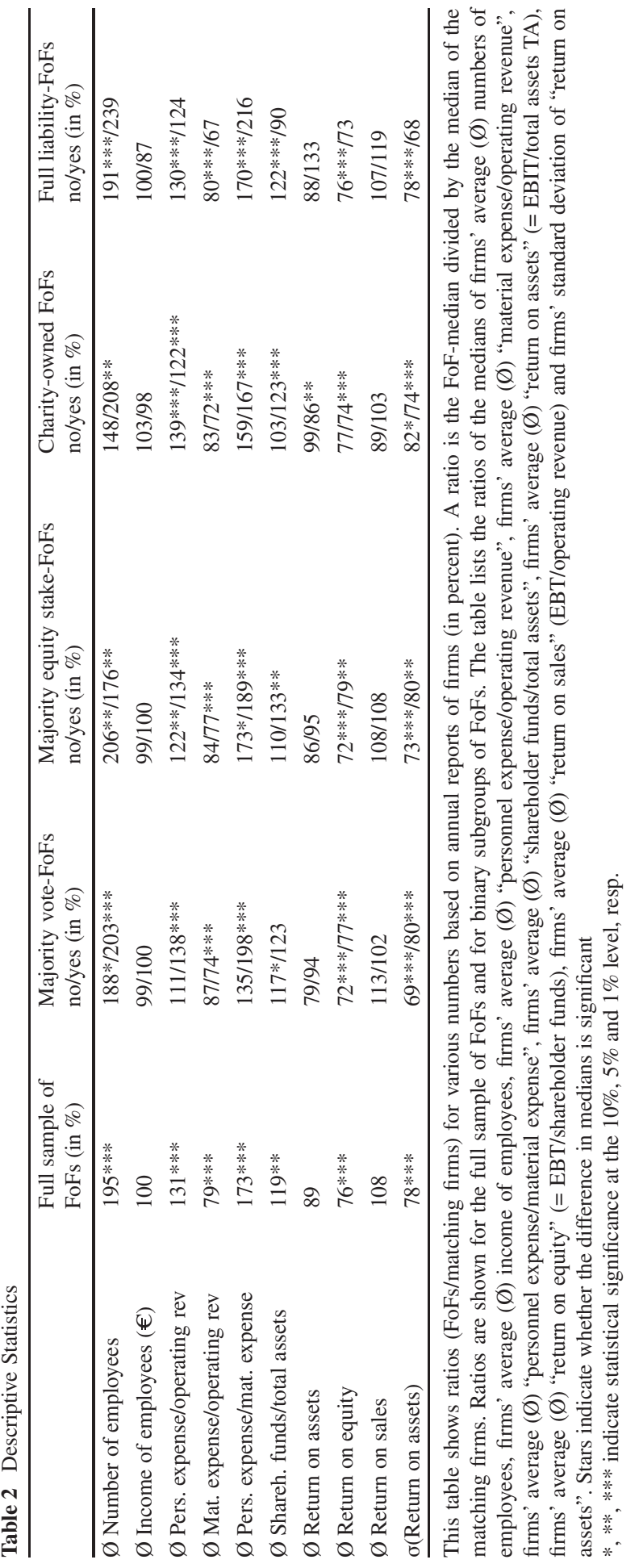


The observation that FoFs tend to be larger than matching firms raises the question whether matching by size makes sense. Organization structures and CG mechanisms tend to become more complex with firm size. A wide range of sizes is covered by our samples of FoFs and matching firms so that complexity should vary within each sample. Matching by size should match relatively weak/strong complexity of FoFs with the same of matching firms. Yet, a size-driven complexity-bias of FoFs may remain, hence the findings should be interpreted with caution. This motivates robustness tests with a smaller number of matching firms and, thus, smaller size differences.

Table 2 displays items for all FoFs and for subgroups. We distinguish binary subgroups of FoFs where the foundation:

- has at least $50 \%$ of voting rights (Majority vote, yes) or not (..., no),

- has at least $50 \%$ of the equity-cash flow rights (Majority equity, yes) or not (..., no),

- is charitable (Charity-owned, yes) or not, i.e. a family foundation (..., no),

- is a partner with unlimited liability (Full liability, yes) or not (..., no).

The full liability-FoFs are a subset of those with ownership of a family foundation. Table 2 displays the median of the FoFs, divided by the median of the matching firms. To facilitate reading, we only report the ratio of the medians. Thus, a ratio of more than $100 \%$ indicates a lower median of the matching firms. We check the significance of the median differences by the Pearson chi-squared-test.

The first line in Table 2 shows that FoFs employ on average about twice as many people as matching firms. The difference in medians is strongly significant, supporting Hypothesis 1b. This also holds for all subgroups of FoFs, except for no-charity-owned FoFs and the subset of full liability-FoFs. This supports weaker employee orientation of FoFs with ownership of a family foundation (Hypothesis 5).

Employment and Production Policy To further characterize business policy and financial performance of firms, we use firm ratios. For each firm an average ratio a / $\mathrm{b}$ is the average of its annual ratios.

The average income of employees (= personnel expense / number of employees) appears to be very similar for FoFs and matching firms falsifying Hypothesis 1a. Apparently, employees do not exploit FoFs through higher income, in contrast to what $\mathrm{S} \& \mathrm{~V}$ might expect. This effect might also be driven by the typical German industry-wide standard wages.

Hypothesis 2 states that the ratio "Personnel expense / operating revenue" should be higher for FoFs, while the ratio "Material expense / operating revenue" should be lower. The $3^{\text {rd }}$ and the $4^{\text {th }}$ line of Table 2 support this hypothesis. Differences in medians are strongly significant for all FoFs and for most subgroups. Hence, "Personnel expense / material expense" is much higher for FoFs relative to matching firms ( $5^{\text {th }}$ line of Table 2$)$.

We also check the ratio "Personnel expense / depreciation" (not shown). Orbis always reports the sum of depreciation and amortization under the heading "depreciation". Differences in medians of FoFs and matching firms are always insignificant. Hence, FoFs appear to use more labor relative to material, but not relative to capital. 
Financing Policy and Financial Performance The last five lines in Table 2 portray financing policy and financial performance. "Shareholder funds / total assets" is higher in FoFs relative to matching firms, except for full liability-FoFs, significance of differences is mixed. Leverage policy appears to be more conservative in FoFs supporting Hypothesis 3, in particular when the foundation is charitable, in line with Hypothesis 5. As a check, we define cash flow as net income plus depreciation including amortization and find that the ratio "Cash flow / (total assets - shareholder funds)" provides a similar answer (not shown).

One might expect that, due to a lower leverage, FoFs pay lower average interest rates on bank debt and other long-term debt relative to matching firms. This is, however, not supported by the frequency distribution of the average interest rates paid (not shown). This suggests that creditors provide credit to FoFs at "normal" interest rates if FoFs protect creditors through lower leverage. This policy may also be driven by the restricted possibilities of FoFs to raise new equity capital. In interviews $95 \%$ of FoF-managers view this as a problem. $24 \%$ consider it a strong disadvantage (Institut für Demoskopie 2012).

The next lines in Table 2 show "Return on assets", "Return on equity", and "Return on sales". Return on assets is EBIT / total assets. EBIT is defined as operating profit / loss, excluding financial profit / loss, extraordinary expenses / revenues and income taxes. The median return on assets (RoA) is lower for all FoFs $(6.7 \%)$ than for matching firms $(7.5 \%)$ and also for all subgroups except for full liability-FoFs. But the difference in medians is significant only for charity-owned FoFs. This provides weak evidence that FoFs earn lower returns on assets than matching firms (supporting Hypothesis 4 and, thus, S \& V).

Splitting FoFs and matching firms into quartiles of operating revenue reveals a differentiated picture. The median RoA of FoFs is lowest (highest) in the lowest (highest) OR-quartile, but this is reversed for the matching firms (not shown). This suggests more effective governance in larger FoFs and/or economies of scale for FoFs, but diseconomies of scale for matching firms. CG of small foundations may be weak, due to little transparency of the foundation and little expertise of foundation managers. These may be dignitaries without a business background and with little or no pay. These deficiencies are less likely in large foundations. This may explain higher returns on assets in larger FoFs.

The evidence is quite different for the return on equity, defined as EBT / equity capital. EBT is EBIT \pm financial profit / loss. All FoFs and most subgroups have significantly lower returns on equity than matching firms. The explanation is that, apart from full liability-FoFs, most FoFs have relatively more equity capital. "Return on sales" again provides a different picture. The median is insignificantly higher for all FoFs and for subgroups. Presumably operating revenues of many FoFs are condensed by more vertical integration.

Financial performance also takes risk into account. As a proxy we use the standard deviation of the firm's RoA, $\sigma$ (RoA), derived from the time series of the firm's RoA. Risk is significantly lower for FoFs $(3.7 \%)$ than for matching firms $(4.8 \%)$ 
(last line of Table 2) ${ }^{8}$. This also holds for all subgroups of FoFs except for full liability-FoFs. Thus, FoF-managers tend to follow less risky policies which may stabilize employment. This is not surprising because, relative to owner-managers in a family firm, FoF-managers and employees likely have fewer possibilities to diversify their risk (Eisenhardt 1989; Pepper and Gore 2015). As both, the average RoA and $\sigma$ (RoA), are lower for FoFs relative to matching firms, only a joint analysis allows a comparison of risk-adjusted financial performance.

\section{Regression Results}

Methods Next, we apply regression methods. Panel regressions with firm fixed effects capture time-invariant heterogeneity of firms. Random effects are infeasible because the residuals strongly correlate with explanatory variables (Hausman-test). We employ panel regressions in two ways. (A) When we analyze Cobb-Douglas functions and the hiring and firing policy of firms, we estimate sensitivities to explanatory variables for different subsets of firms. If differences between sensitivities are significant, then this indicates different firm policies. (B) In all other cases we follow a two step-procedure. First, we panel-regress a time-dependent variable on other time-dependent variables, including control variables, to estimate the fixed effect for every firm. We also run this regression with different sensitivities for FoFs and matching firms. As the sensitivities never differ significantly, we estimate the firm fixed effects from regressions with unique sensitivities for all firms. Second, we OLS-regress the firm fixed effects on dummy variables including industry dummies and time-invariant control variables, to find out the impact of foundation ownership and codetermination. An error in variables-problem may affect the estimation of the firm fixed effects. A way around this problem is the Hausman-Taylor method (Hausman and Taylor 1981). It requires suitable instrumental variables which are difficult to find in our setting. Therefore, we follow Lewis and Linzer (2005, p. 363) who conclude: "Indeed, OLS with robust standard errors is probably the best approach, except when information about the sampling in the dependent variable is not only available, but highly reliable". For large samples they suggest to use White standards errors, correcting for heteroscedasticity. We do this.

Estimating corporate policies always faces endogeneity issues. As management decides about corporate policy, it has a strong impact on most accounting numbers so that they are not independent. CG manifests itself in these dependencies. These should not be misinterpreted as causalities. Empirical estimates might be biased by this endogeneity. Our premise is that estimated differences between subsets of firms are robust to these biases. We check for differences in regression sensitivities between FoFs and matching firms as explained before. As the estimated sensitivities

\footnotetext{
8 It is well known that larger firms tend to have lower risk due to more diversification of their activities. But a linear regression of the standard deviations of return on assets shows that the larger size of FoFs can only explain a small part of the negative difference in standard deviations between FoFs and matching firms. Thus, FoFs appear to play a safer game.
} 
do not differ significantly, a potential endogeneity bias should be similar for FoFs and matching firms. Robustness checks help to avoid biased conclusions.

\subsection{Employment and Production Policy}

Average Income of Employees Descriptive statistics show no differences in average income of employees between FoFs and matching firms. We also OLS-regress the average income of employees of a firm, averaged over the sampling period, on a FoF-dummy [= 1 for a FoF and 0 otherwise], a codetermination dummy [= 1 for a codetermined firm and 0 otherwise] and an interaction term of both dummies. We control for industry effects. All variables turn out to be insignificant (not shown). Hence foundation ownership and codetermination do not raise the average income of employees, invalidating the skepticism of S \& V.

Cobb-Douglas Function To analyze production policy, we use panel regressions to estimate the Cobb-Douglas functions for subsets of firms. Even though it is common to estimate translog-production functions with linear and quadratic terms, we only use linear terms to estimate the elasticities of operating revenue with respect to these expenses.

The first column of Table 3 shows the elasticities, estimated separately for all FoFs and their matching firms, and the differences between these elasticities. The elasticities for personnel expense, material expense and depreciation add up to about 0.96 for the FoFs, and 0.66 for the matching firms. The elasticity for personnel expense is more than twice as high for FoFs than for matching firms, the difference is significant. The elasticity for material expense is insignificantly lower for FoFs than for matching firms. Apparently, FoFs are more labor intensive, supporting Hypothesis 2 . The strong difference in personnel expense-elasticities and the weak difference in material expense-elasticities suggest that FoFs may substitute labor for material, but also focus more on services and labor intensive products. The elasticities for depreciation are small and not significantly different. Thus, substitution of labor for capital in FoFs is not supported.

The second, third and fourth column in Table 3 show the results for limited liability-FoFs, no-charity-owned and charity-owned FoFs, respectively. The qualitative results are similar to "all FoFs". But the elasticity differences are much stronger for FoFs owned by charitable than those owned by family foundations, in line with Hypothesis 5 and concerns of $\mathrm{S} \& \mathrm{~V}$.

In order to check whether codetermination has similar effects as foundation ownership, we rerun the first regression in Table 3 for codetermined firms only (not shown). 68 of the 164 FoFs and 238 of the 758 matching firms are codetermined. We find elasticities of operating revenue to personnel expense of 0.725 (strongly significant) for the codetermined FoFs and 0.084 (insignificant) for codetermined matching firms. The difference between these sensitivities is almost doubled relative to column 1 in Table 3 and highly significant. The negative difference of the elasticities with respect to material expense is more than doubled, but stays insignificant. These results suggest that foundation ownership and codetermination jointly raise labor intensity. To strengthen this finding, we run another test. 
Table 3 Cobb Douglas Function

\begin{tabular}{|c|c|c|c|c|}
\hline$\overline{\ln \mathrm{OR}}$ & All FoFs & $\begin{array}{l}\text { Lim Liability- } \\
\text { FoFs }\end{array}$ & $\begin{array}{l}\text { No-Charity-owned } \\
\text { FoFs }\end{array}$ & $\begin{array}{l}\text { Charity-owned } \\
\text { FoFs }\end{array}$ \\
\hline \multicolumn{5}{|l|}{$\ln P E$} \\
\hline mat & $0.202 * *$ & $0.229 * *$ & $0.217 * * *$ & $0.258^{*}$ \\
\hline $\mathrm{FoF}$ & $0.574 * * *$ & $0.573 * * *$ & $0.399 * * *$ & $0.729 * * *$ \\
\hline Difference & $0.372 * *$ & $0.344^{*}$ & 0.182 & $0.471^{* *}$ \\
\hline \multicolumn{5}{|l|}{$\ln M E$} \\
\hline mat & $0.427 * * *$ & $0.406^{* * * *}$ & $0.585^{* * *}$ & $0.344 * * *$ \\
\hline FoF & $0.345^{* *}$ & $0.340 * *$ & $0.561 * * *$ & 0.189 \\
\hline Difference & -0.082 & -0.066 & -0.024 & -0.155 \\
\hline \multicolumn{5}{|l|}{$\ln D E$} \\
\hline mat & $0.033 * *$ & 0.024 & $0.029 *$ & 0.037 \\
\hline FoF & 0.040 & 0.044 & 0.036 & 0.009 \\
\hline Difference & 0.007 & 0.020 & 0.013 & -0.028 \\
\hline Within $\mathrm{R}^{2}$ & 0.6869 & 0.6798 & 0.8135 & 0.6622 \\
\hline \# of obs & 5052 & 4557 & 1802 & 3148 \\
\hline
\end{tabular}

This table shows the results of panel regressions estimating the Cobb-Douglas function: $\ln \mathrm{OR}_{\mathrm{i}, \mathrm{t}}=$ $\alpha \ln \mathrm{PE}_{\mathrm{i}, \mathrm{t}}+\beta \ln \mathrm{ME}_{\mathrm{i}, \mathrm{t}}+\gamma \mathrm{DE}_{\mathrm{i}, \mathrm{t}}+\mathrm{v}_{\mathrm{i}}+\varepsilon_{\mathrm{i}, \mathrm{t}}$. PE is personnel expense, ME material expense, and DE depreciation. $v_{i}$ is the fixed effect for firm $i$. The coefficients are estimated separately for matching firms (mat) and for FoFs. Difference is "coefficient for FoFs-coefficient for matching firms", with asterisks indicating significance. The first column includes all FoFs and their matching firms, the other columns include only subsets of FoFs and their matching firms. Year dummies and regression constants are included, but not shown. Standard errors are adjusted for clustering (firm) effects and heteroscedasticity.

$*, * *, * * *$ statistically significant at $10 \%, 5 \%, 1 \%$

A Simple Test of Labor Intensity The ratio "Personnel expense/material expense" (PPM) should increase with labor intensity and, thus, be higher in FoFs. We test this in a two step-procedure. In the first step, we panel-regress PPM on operating revenue, leverage and leverage squared to estimate firm fixed effects. We include leverage as a control variable because it might affect employment. The negative sensitivity of PPM to ln OR in Table 4 is no surprise as a substantial part of personnel expense is a fixed expense, but material expense is mostly variable. Leverage effects are insignificant.

In the second step, we OLS-regress the firm fixed effects on various FoF-characteristics. The positive coefficient of the FoF-dummy is strongly significant indicating that labor intensity is clearly higher in FoFs than in matching firms (Table 5, first regression). In the next regression, the coefficient for charity-owned FoFs is significant and more than twice than that for no-charity-owned FoFs. As their difference is insignificant, Hypothesis 5 is only weakly supported. Limited versus full liability of FoFs does not matter ( $3^{\text {rd }}$ regression). Also the vote and the equity share of the foundation have no significant impact $\left(4^{\text {th }} \text { and } 5^{\text {th }} \text { regression }\right)^{9}$. Overall, these regressions support Hypothesis 2 that FoFs are more labor intensive than matching firms. In the last regression, both, foundation ownership and codetermination have

${ }^{9}$ In all regressions we test for linear effects of the vote share and the equity share. They are never significant (not shown) except for Table 11. 
Table 4 Analysis of the "Personnel expense/material expense"-ratio (PPM)

\begin{tabular}{ll}
\hline PPM & Regression coefficients \\
\hline $\ln$ OR & $-0.558^{*}$ \\
lev & -0.048 \\
$\operatorname{lev}^{2}$ & 0.085 \\
Within $R^{2}$ & 0.0097 \\
$\#$ of jobs & 5378 \\
\hline
\end{tabular}

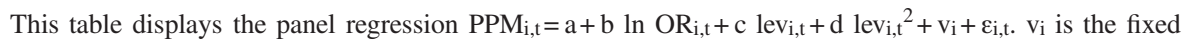
effect for firm i. levi,t is (1-shareholder funds / total assets) of firm i in year t. Year dummies and regression constants are included, but not shown. Standard errors are adjusted for clustering (firm) effects and heteroscedasticity.

$*, * *, * * *$ statistically significant at $10 \%, 5 \%, 1 \%$

Table 5 Analysis of the "Personnel expense/material expense"-ratio (PPM)

\begin{tabular}{lllllll}
\hline Firm fixed effects & \multicolumn{7}{l}{ Regression Coefficients } & & \\
\hline FoF & $1.301^{* * *}$ & - & - & $2.401^{*}$ & $1.879^{* *}$ & $1.507^{* *}$ \\
no-char-FoF & - & 0.689 & - & - & - & - \\
char-FoF & - & $1.639^{* *}$ & - & - & - & - \\
Difference & - & -0.950 & - & - & - & - \\
lim liab-FoF & - & - & $1.276^{* *}$ & - & - & - \\
full liab-FoF & - & - & 1.557 & - & - & - \\
difference & - & - & -0.281 & - & - & - \\
FoF $\times$ vote share & - & - & - & -1.540 & - & - \\
FoF $\times$ equity share & - & - & - & - & -1.041 & - \\
codetermin. & - & - & - & - & - & $1.127^{* * *}$ \\
FoF $\times$ codetermin & - & - & - & - & - & -0.803 \\
adj R & 0.2152 & 0.2161 & 0.2142 & 0.2165 & 0.2155 & 0.2221 \\
$\#$ of obs & 778 & 761 & 778 & 778 & 778 & 778 \\
\hline
\end{tabular}

This table displays OLS-regressions of firm fixed effects $\mathrm{v}_{\mathrm{i}}$, derived in Table 4. FoF, no-char-FoF (= nocharity owned FoF), char-FoF ( = charity owned FoF), lim liab-FoF (= limited liability-FoF) and full liab$\mathrm{FoF}(=$ unlimited liability-FoF) are dummies which are equal to 1 if a firm is of that type, 0 otherwise. "FoF $\times$ vote share" and "FoF $\times$ equity share" are interaction variables of the FoF-dummy and the foundation's vote share resp. the equity share in the FoF. "Difference" denotes difference between the two sensitivities above in the same column, with asterisks indicating significance. "codetermin." is a dummy for codetermined firms, "FoF $\times$ codetermin." the interaction term for foundation ownership and codetermination. Industry dummies and regression constants are included, but not shown. Significance is based on White standard errors correcting for heteroscedasticity.

$*, * *, * * *$ statistically significant at $10 \%, 5 \%, 1 \%$

strongly significant positive effects on labor intensity. These effects are similar and rather independent as the interaction term is insignificant. ${ }^{10}$

Hiring and Firing Policy Job security is likely important for most employees. Therefore we analyze annual hiring and firing policies. Orbis shows the annual

10 The ratio "Personnel expense / material expense" could be biased by differences in average incomes of employees. Including this in Table 5 as a control variable has no significant effect (not shown). 
numbers of employees of firms. Annual changes in these numbers, i.e. fluctuation, are composed of employee-motivated fluctuation (employees leave because of retirement or other personal reasons) and firm-driven fluctuation (the firm hires and fires employees). Since firms do not publish data on fluctuation motives, we relate fluctuation to changes in operating revenue, presumably the most important systematic driver apart from mergers, acquisitions, and spin-offs. We measure fluctuation by annual relative changes in personnel expense. As this expense can change without hiring and firing, we also analyze relative changes in the number of employees. Firms may react differently to positive and negative changes in operating revenue, therefore we estimate sensitivities separately.

$$
\frac{\mathrm{PE}_{\mathrm{i}, \mathrm{t}}}{\mathrm{PE}_{\mathrm{i}, \mathrm{t}-1}}=\mathrm{a}+\mathrm{bOR}_{\mathrm{i}, \mathrm{t}}^{+}+\mathrm{cOR}_{\mathrm{i}, \mathrm{t}}^{-}+\mathrm{v}_{\mathrm{i}}+\text { year dummies }+\varepsilon_{\mathrm{i}, \mathrm{t}}
$$

with:

$$
\mathrm{OR}_{\mathrm{i}, \mathrm{t}}^{+}=\max \left(\mathrm{OR}_{\mathrm{i}, \mathrm{t}} / \mathrm{OR}_{\mathrm{i}, \mathrm{t}-1}-1,0\right)
$$

and:

$$
\mathrm{OR}_{\mathrm{i}, \mathrm{t}}^{-}=\min \left(\mathrm{OR}_{\mathrm{i}, \mathrm{t}} / \mathrm{OR}_{\mathrm{i}, \mathrm{t}-1}-1,0\right)
$$

$\mathrm{PE}_{\mathrm{i}, \mathrm{t}}$ and $\mathrm{OR}_{\mathrm{i}, \mathrm{t}}$ are the personnel expense and the operating revenue of firm $\mathrm{i}$ in year $t . v_{i}$ is the firm fixed effect capturing firm heterogeneity. We estimate the regression coefficients separately for matching firms, limited liability- and full liabilityFoFs.

Table 6, left hand side, reports the findings for personnel expense. The table also shows the differences between the group-coefficients and their significance levels. The sensitivity of personnel expense growth to positive operating revenue growth is similar for limited liability-FoFs and matching firms, but very weak for full liabilityFoFs. The sensitivity to negative OR growth is also similar for matching firms and limited liability-FoFs, but significantly stronger for full liability-FoFs. They appear to react much stronger by cutting personnel expense, perhaps because their leverage is high, i.e. their financial reserves are low (Table 2). The right hand side of Table 6 confirms the results for the number of employees. Employment reacts weaker than personnel expense to operating revenue, except for full liability-FoFs. This indicates that firms use flexibility in working hours and temporary workers to accommodate changes in operating revenue before they hire or fire "permanent" employees.

Firms may react stronger to larger changes in OR. Therefore we repeat the exercise in Table 7, but consider only annual changes in OR of at least 10\%. Except for full liability-FoFs, all significant coefficients turn out to be higher as expected, but differences between FoFs and matching firms remain insignificant ${ }^{11}$. We also

\footnotetext{
11 When we control for the average income of employees, it has a significant positive impact in the regressions for the personnel expense, but not in those for the number of employees (not shown). Increases in personal expense are inflated by the average income of employees.
} 
Table 6 Hiring and Firing Policy

\begin{tabular}{llllll}
\hline $\mathrm{PE}_{\mathrm{t}} / \mathrm{PE}_{\mathrm{t}-1}$ & Coeff & Differences & $\mathrm{EMP}_{\mathrm{t}} / \mathrm{EMP}_{\mathrm{t}-1}$ & Coeff & Differences \\
\hline $\mathbf{O R}_{\mathbf{t}}^{+}$ & & & $\mathbf{O R}_{\mathbf{t}}^{+}$ & & \\
mat & $0.409^{* * *}$ & $-0.050 /-0.228^{* *}$ & mat & $0.155^{* * *}$ & $-0.021 / 0.146$ \\
lim liab & $0.359^{* * *}$ & -0.178 & lim liab & $0.134^{*}$ & 0.167 \\
full liab & 0.181 & & full liab & $0.301^{* * *}$ & \\
$\mathbf{O R}_{\mathbf{t}}^{-}$ & & & $\mathbf{O R}_{\mathbf{t}}^{-}$ & & \\
mat & $0.270^{* * *}$ & $0.007 / 0.297 * * *$ & mat & $0.142^{* * *}$ & $0.078 / 0.129$ \\
lim liab & $0.277^{* * *}$ & $0.290^{* *}$ & lim liab & $0.220^{* *}$ & 0.051 \\
full liab & $0.567^{* * *}$ & & full liab & $0.271^{* * *}$ & \\
within $\mathrm{R}^{2}$ & 0.2895 & & within $\mathrm{R}^{2}$ & 0.0764 & \\
\# of obs & 5346 & & \# of obs & 4822 & \\
\hline
\end{tabular}

This table shows the results for Eq. 2 , based on all annual changes in OR

This table shows the results of panel regressions with firm fixed effects estimating hiring and firing policy. Sensitivities are estimated separately for matching firms (mat), limited liability-FoFs (lim liab) and full liability-FoFs (full liab). On the left hand side $\mathrm{PE}_{t} / \mathrm{PE}_{\mathrm{t}-1}$ is the dependent variable, on the right hand side it is $\mathrm{EMP}_{\mathrm{t}} / \mathrm{EMP}_{\mathrm{t}-1}$. PE is personnel expense, EMP the number of employees. Year dummies and regression constants are included, but not shown. "Differences" are differences between coefficients of the same regressor, with asterisks indicating significance. They are presented like in a covariance matrix. The first difference is that between mat and lim liab, the second is that between mat and full liab, and in the line below the third is that between lim and full liab. Standard errors are adjusted for clustering (firm) effects and heteroscedasticity

$*, * *, * * *$ statistically significant at $10 \%, 5 \%, 1 \%$

Table 7 Hiring and Firing Policy

\begin{tabular}{llllll}
\hline $\mathrm{PE}_{\mathrm{t}} / \mathrm{PE}_{\mathrm{t}-1}$ & Coeff & Differences & $\mathrm{EMP}_{\mathrm{t}} / \mathrm{EMP}_{\mathrm{t}-1}$ & Coeff & Differences \\
\hline $\mathbf{O R}_{\mathbf{t}}{ }^{++}$ & & & $\mathbf{O R}_{\mathbf{t}}^{++}$ & & \\
mat & $0.485^{* * *}$ & $-0.080 /-0.381^{* * *}$ & mat & $0.176^{* * *}$ & $-0.017 / 0.085$ \\
lim liab & $0.405^{* * *}$ & $-0.301^{*}$ & $\operatorname{lim~liab}$ & $0.159^{*}$ & 0.102 \\
full liab & 0.104 & & full liab & $0.261^{*}$ & \\
$\mathbf{O R}_{\mathbf{t}}^{--}$ & & & $\mathbf{O R}_{\mathbf{t}}^{--}$ & & \\
mat & $0.442^{* * *}$ & $0.005 / 0.320^{* * *}$ & mat & $0.213^{* * *}$ & $0.106 / 0.238^{* *}$ \\
lim liab & $0.447^{* * *}$ & $0.315^{*}$ & lim liab & $0.319^{* * *}$ & 0.132 \\
full liab & $0.762^{* * *}$ & & full liab & $0.451^{* * *}$ & \\
within $\mathrm{R}^{2}$ & 0.2764 & & within $\mathrm{R}^{2}$ & 0.0693 & \\
\# of obs & 5346 & & \# of obs & 4822 & \\
\hline
\end{tabular}

This table shows the results for Eq. 2 , based on annual changes in OR of at least 10\%

This table shows the results of panel regressions with firm fixed effects estimating hiring and firing policy. Sensitivities are estimated separately for matching firms (mat), limited liability-FoFs (lim liab) and full liability-FoFs (full liab). On the left hand side $\mathrm{PE}_{t} / \mathrm{PE}_{\mathrm{t}-1}$ is the dependent variable, on the right hand side it is $\mathrm{EMP}_{\mathrm{t}} / \mathrm{EMP}_{\mathrm{t}-1}$. PE is personnel expense, EMP the number of employees. Year dummies and regression constants are included, but not shown. "Differences" are differences between coefficients of the same regressor, with asterisks indicating significance. They are presented like in a covariance matrix. The first difference is that between mat and lim liab, the second is that between mat and full liab, and in the line below the third is that between lim and full liab. Standard errors are adjusted for clustering (firm) effects and heteroscedasticity

$*, * *, * * *$ statistically significant at $10 \%, 5 \%, 1 \%$ 
analyze charity-owned FoFs, no-charity-owned FoFs and their matching firms. The estimated sensitivities for these groups are not significantly different (not shown). This invalidates Hypotheses 1c and 5. Again we rerun the regressions in Table 7 for codetermined firms only. In this subset there are almost no foundations with full liability. For the other FoFs and for the matching firms the estimated sensitivities turn out to be somewhat higher, but the differences remain insignificant (not shown). This indicates that codetermination does not mitigate hiring and firing. Summarizing, our findings do not support Hypothesis 1c, FoFs and codetermined firms do not follow a more lenient short term-hiring and firing policy, invalidating concerns of $\mathrm{S} \& \mathrm{~V}$.

Number and Income of Top Managers Even though FoFs and matching firms pay about the same average income to employees, top managers in FoFs might be more powerful and earn a higher income. Therefore, we check the total income and the per capita income of the management board. The German commercial code requires corporations to publish these numbers unless the management board has only one member or the corporation is small. We have the data for 55 FoFs and for 192 matching firms. The median of the average number of board members over the sampling period is 4 for FoFs and 3.5 for matching firms. This indicates that the board is only slightly larger in FoFs even though FoFs tend to be much larger. We first panel-regress total income of board members and their per capita-income on ln OR, earnings before interest and taxes (EBIT) and leverage to derive firm fixed effects. Then we OLS-regress these on various dummies, controlling for industry effects. The FoF-dummy is positive with a $p$-value of 0.092 for total board income, but completely insignificant for per capita income. Other firm characteristics are also completely insignificant (not shown). Thus, we find no evidence for entrenchment of managers in FoFs which is at odds with $\mathrm{S} \& \mathrm{~V}$.

A short summary of this section: Managers and other employees apparently do not earn higher income in FoFs or codetermined firms. Also, FoFs and codetermined firms do not appear to follow more lenient annual (short term)-hiring and firing policies. But these firms are more labor intensive, indicating more job security in the long term. They are larger, substitute labor for material, but not for capital. These effects are somewhat stronger for FoFs owned by charitable relative to non-charitable foundations. Thus, Hypotheses 1 and 5 are partially supported. Privileged employee orientation exists in FoFs, but we observe conservative instead of aggressive packages of employee benefits. Apparently employees pursue a long term-policy of corporate stability, thus invalidating the skepticism of S \& V.

\subsection{Leverage and Payout Policy}

As argued before, a conservative financing policy may be in the interest of all stakeholders except for residual claimants. Hypothesis 3 states that this policy is more conservative in FoFs than in matching firms. First, we OLS-regress a firm's ratio "equity / total assets", averaged over the sampling period, on a FoF-dummy, a codetermination-dummy and their interaction term and control for industry effects. As expected, the FoF-dummy is positive and strongly significant, supporting Hy- 
pothesis 3. Both codetermination terms are insignificant (not shown). In our sample codetermination does not affect leverage, in contrast to Fauver and Fuerst (2006).

Second, FoFs can also strengthen their equity capital by lower payouts to owners. For anecdotal evidence, the big FoFs Bosch, Mahle and Körber owned by charity foundations paid out about 3,4 , and $10 \%$, respectively, of their net income, compared to an average of $40 \%$ for the big German corporations listed in the DAX. Our sample is composed of corporations and partnerships. As there is no official payout in partnerships, we analyze:

$$
\begin{aligned}
\text { net payout }_{\mathrm{i}, \mathrm{t}} & =\text { equity payout }_{\mathrm{i}, \mathrm{t}}-\text { newly raised equity }_{\mathrm{i}, \mathrm{t}} \\
& =\text { net income } \\
\mathrm{i}, \mathrm{t} & + \text { equity capital }_{\mathrm{i}, \mathrm{t}-1}-\text { equity capital }_{\mathrm{i}, \mathrm{t}} .
\end{aligned}
$$

The net payout in year t may be driven by the firm's return on equity and the deviation of its leverage from a target-leverage (Hovakimian 2004). As the cost of financial distress may increase with leverage in a convex manner, the payout ratio might react non-linearly to leverage (lev). Therefore, we also include the squared leverage in the regression for the payout ratio $\operatorname{PoR}_{\mathrm{i}, \mathrm{t}}\left(:=\right.$ net payout $_{\mathrm{i}, \mathrm{t}} /$ equity $\left._{\mathrm{i}, \mathrm{t}-1}\right)$. This ratio may react differently to positive $\left[\operatorname{RoE}_{\mathrm{i}, \mathrm{t}-1}^{+}\right]$and negative $\left[\mathrm{RoE}_{\mathrm{i}, \mathrm{t}-1}^{-}\right]$returns on equity. $v_{i}$ is the fixed effect for firm $i$.

$$
\operatorname{PoR}_{\mathrm{i}, \mathrm{t}}=\mathrm{a}+\mathrm{bRoE} \mathrm{R}_{\mathrm{i}, \mathrm{t}-1}^{+}+\mathrm{cRoE}_{\mathrm{i}, \mathrm{t}-1}^{-}+\mathrm{dlev}_{\mathrm{i}, \mathrm{t}-1}+\mathrm{elev}_{\mathrm{i}, \mathrm{t}-1}^{2}+\mathrm{v}_{\mathrm{i}}+\varepsilon_{\mathrm{i}, \mathrm{t}}
$$

The payout ratio may be smaller than -1 in some years because of substantial new equity issues. It may be higher than 1 because of spin-offs and other divestments. These cases are not representative of the normal payout policy. Also, payout ratios tend to be extreme when equity is close to 0 . Therefore, we exclude payout ratios below -0.9 and above 0.9 . Moreover, we exclude firms with negative equity.

The first regression of Table 8 includes only payout ratios between -0.9 and 0.9 , the next regression only ratios between -0.8 and 0.8 , and so on. The payout ratio increases significantly with a higher positive return on equity. But there is no significant reaction to a negative return on equity. Firms may stop net payouts or pay (small) fixed amounts when they incur losses. Leverage has no significant impact,

Table 8 Analysis of the Payout Ratio

\begin{tabular}{lllll}
\hline $\mathrm{PoR}_{\mathrm{t}}$ & $(-0.9 ; 0.9)$ & $(-0.8 ; 0.8)$ & $(-0.5 ; 0.5)$ & $(-0.4 ; 0.4)$ \\
\hline $\mathrm{RoE}_{\mathrm{t}-1}^{+}$ & $0.076^{* * *}$ & $0.066^{* * *}$ & $0.022^{*}$ & $0.022^{* *}$ \\
$\mathrm{RoE}^{-} \mathrm{t}-1$ & 0.028 & -0.001 & -0.033 & -0.026 \\
$\mathrm{lev}_{\mathrm{t}-1}$ & -0.044 & -0.091 & -0.105 & -0.160 \\
$\mathrm{lev}_{\mathrm{t}-1}^{2}$ & $-0.337 * *$ & $-0.251^{*}$ & -0.110 & -0.032 \\
within $\mathrm{R}^{2}$ & 0.0824 & 0.0683 & 0.0493 & 0.0570 \\
$\#$ of obs & 3399 & 3376 & 3247 & 3186 \\
\hline
\end{tabular}

This table displays the findings for the panel regression of the payout ratio (Eq. 3). Only firms are included that have positive equity in the whole sample period. Firm fixed effects, year dummies, and regression constants are included, but not shown. Standard errors are adjusted for clustering (firm) effects and heteroscedasticity

$*, * *, * * *$ statistically significant at $10 \%, 5 \%, 1 \%$ 
Table 9 Analysis of the Payout Ratio

\begin{tabular}{lllll}
\hline Firm fixed effects & $(-0.9 ; 0.9)$ & $(-0.8 ; 0.8)$ & $(-0.5 ; 0.5)$ & $(-0.4 ; 0.4)$ \\
\hline FoF & $-0.042^{* *}$ & $-0.033^{* * *}$ & $-0.030^{* * *}$ & $-0.024 * * *$ \\
IFRS & $-0.087^{* * *}$ & $-0.079 * * *$ & -0.031 & -0.020 \\
adj. $\mathrm{R}^{2}$ & 0.0447 & 0.0447 & 0.0306 & 0.0196 \\
$\#$ of obs & 558 & 556 & 551 & 548 \\
\hline
\end{tabular}

This table displays OLS-regressions of firm fixed effects, derived in Table 8. FoF and IFRS are dummies which are equal to 1 if a firm is an FoF, resp. if the firm uses IFRS. Only firms are included which do not switch from IFRS to German accounting standards or vice versa in the sample period. Industry dummies and regression constants are included, but not shown. Significance is based on White standard errors correcting for heteroscedasticity

$*, * *, * * *$ statistically significant at $10 \%, 5 \%, 1 \%$

but squared leverage has a significant negative impact when payout ratios in the range \pm 0.9 or \pm 0.8 are considered. This suggests that the marginal decline in the payout ratio increases in leverage.

Next, we OLS-regress the estimated firm fixed effects on the FoF-dummy (Table 9). For all ranges of payout ratios, the FoF-dummy is negative and strongly significant. That indicates lower payout ratios of FoFs in support of Hypothesis 3 and in line with $\mathrm{S} \& \mathrm{~V}$ who are worried about potential generous spending. We do not find higher payout ratios for firms (partially) owned by family foundations relative to charitable foundations (not shown), invalidating Hypothesis 5. When we include a codetermination-dummy and an interaction term with the FoF-dummy in Table 9, both variables have insignificant effects (not shown). Codetermination does not affect the payout policy in our sample.

The payout ratio is negatively affected by IFRS accounting ${ }^{12}$. Switching from German accounting rules to IFRS mostly increases equity capital because many assets are valued at market prices instead of historical cost (Hung and Subramanyam 2007). A higher equity lowers the return on equity. This likely explains the negative IFRS effect on the payout ratio.

\subsection{Financial Performance}

Hypothesis 4 claims that privileged employee orientation weakens financial performance. We measure financial performance by the average return on assets (RoA), taking risk $\sigma(\mathrm{RoA})$ into account. First, we panel-regress RoA on operating revenue and on operating revenue growth as RoA reacts sensitively to these variables. Operating revenue growth is a proxy of a firm's aggressiveness for raising its market share even though growth is driven by many factors, e.g. product improvement and innovation by the firm and by its competitors. The median growth rate of operating revenue is insignificantly lower for all FoFs relative to matching firms (not shown). We use leverage and leverage squared as control variables. The free cash

\footnotetext{
12 According to $\S 315$ a (2) of the German Commercial Code listed firms have to publish a consolidated annual statement according to IFRS, beginning in 2005. Non-listed firms can choose to publish a consolidated annual statement according to IFRS or to German accounting rules ( $\$ 315 \mathrm{a}(3)$ ). Non-consolidated annual statements have to be published according to the German accounting rules.
} 
Table 10 RoA-Analysis

\begin{tabular}{llll}
\hline Financial Performance & $\begin{array}{l}\text { EBIT / TA } \\
(1)\end{array}$ & $(2)$ & $\begin{array}{l}\text { EBITDA / TA } \\
(3)\end{array}$ \\
\hline $\ln \mathrm{OR}$ & $0.051^{* * * *}$ & 0.096 & $0.049 * * *$ \\
$(\ln \mathrm{OR})^{2}$ & - & -0.001 & - \\
$\ln \left(\mathrm{OR}_{\mathrm{t}} / \mathrm{OR}_{\mathrm{t}-1}\right)$ & $0.079^{* * *}$ & $0.079 * * *$ & $0.077 * * *$ \\
$\operatorname{lev}$ & $0.150^{* *}$ & $0.148^{* *}$ & $0.135 * *$ \\
$\operatorname{lev}^{2}$ & $-0.247 * * *$ & $-0.244 * * *$ & $-0.230^{* * *}$ \\
within $^{2}$ & 0.1733 & 0.1735 & 0.1695 \\
$\#$ of obs & 5464 & 5464 & 5335 \\
\hline
\end{tabular}

This table shows the findings of a panel regression estimating return on assets $\operatorname{RoA}_{\mathrm{i}, \mathrm{t}}=\mathrm{a}+\mathrm{b} \ln \mathrm{OR}_{\mathrm{i}, \mathrm{t}}+\mathrm{c}$ growth $_{i, t}+\mathrm{dlev}_{\mathrm{i}, \mathrm{t}}+\mathrm{e} \operatorname{lev}_{\mathrm{i}, \mathrm{t}}{ }^{2}+\mathrm{v}_{\mathrm{i}}+\varepsilon_{\mathrm{i}, \mathrm{t}} \cdot \mathrm{RoA}_{\mathrm{i}, \mathrm{t}}=\mathrm{EBIT}_{\mathrm{i}, \mathrm{t}} / \mathrm{TA}_{\mathrm{i}, \mathrm{t}}$. Growth is $\ln \left(\mathrm{OR}_{\mathrm{t}} / \mathrm{OR}_{\mathrm{t}-1}\right) . \mathrm{v}_{\mathrm{i}}$ is the fixed effect for firm i. In the last column, EBIT / TA is replaced by EBITDA / TA. Year dummies and a regression constant are included in the regression, but not shown. Standard errors are adjusted for clustering (firm) effects and heteroscedasticity

$*, * *, * * *$ statistically significant at $10 \%, 5 \%, 1 \%$

flow argument (Jensen 1986; Core et al. 2005) suggests that an increase of a low leverage might constrain generous spending and thereby increase RoA. The effect of a high leverage might be a shortage of funds available for investments leading to underinvestment (Myers 1977). An increase of a high leverage might reinforce this shortage and thereby lower RoA.

RoA increases with $\ln$ OR and with growth of operating revenue (Table 10) as expected. The leverage effect is inversely $\mathrm{u}$-shaped and strongly significant. That supports the free cash flow hypothesis for low levels of leverage and the underinvestment hypothesis for high levels. The inverse u-shape attains it peak at a leverage of 0.26 . Most firms operate at levels above 0.5 , i.e. on the declining part of the curve.

Second, we OLS-regress the firm fixed effects, estimated in the first regression of Table 10, on different firm-characteristics. All regressions in Table 11 except for the last one show a significantly negative coefficient of the FoF-dummy. In support of Hypothesis 4, RoA is significantly smaller in FoFs than in matching firms. In the first regression, the interaction term for charity owned FoFs is insignificant so that ownership of a charitable or a family foundation does not matter for RoA, invalidating Hypothesis 5.

We control for risk by including $\sigma$ (RoA). Its strongly significant positive coefficient shows that firms with higher risk tend to earn higher returns. When we OLSregress $\sigma$ (RoA) on the FoF-dummy, the codetermination dummy and the interaction term, controlling for industry effects, foundation ownership and codetermination have similar strongly significant negative effects on risk, the interaction term is insignificant (not shown). Managerial risk appetite appears to be lower. The IFRSdummy controls for accounting effects. Under IFRS total assets are higher so that RoA is lower.

Codetermination has a strongly significant negative impact on RoA (regression (2) in Table 11). The interaction term "FoF-dummy $\times$ codetermination dummy" is insignificant. Hence both, foundation ownership and codetermination lower RoA in a rather additive manner. The codetermination effect appears to be stronger. 


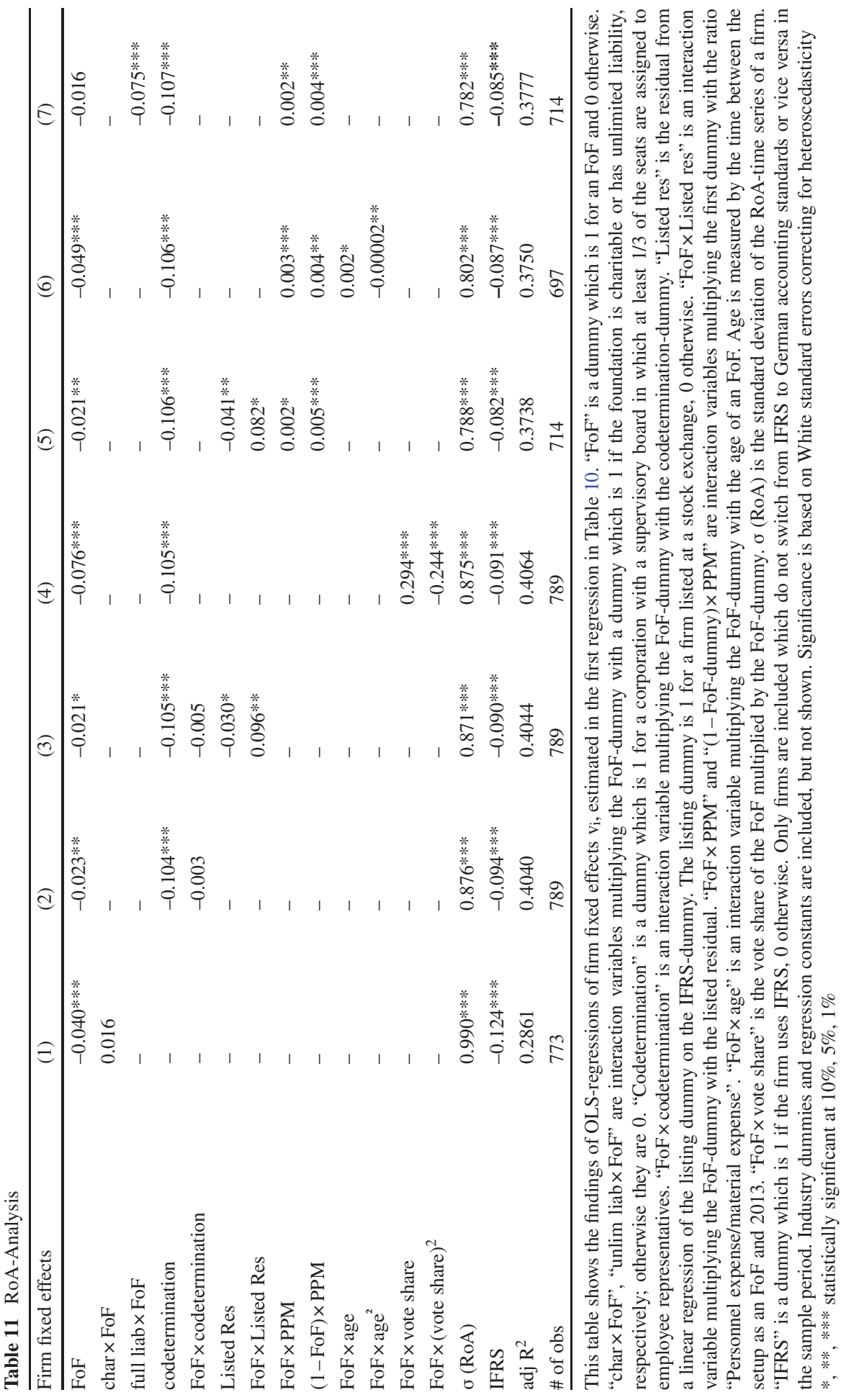


In regressions (3) and (5), we analyze listing effects. 21 of the 164 FoFs are listed which is about 1/8. Among the 757 matching firms 89 are listed, slightly less than 1/8. Each listed firm has to use IFRS. Therefore, the IFRS-dummy and the listingdummy (= 1 for a listed firm and 0 otherwise) are strongly correlated. To avoid multi-collinearity, we first linearly regress the listing dummy on the IFRS-dummy and use the regression residual "Listed res" in Table 11. Surprisingly, "Listed res" has a significant, negative impact on RoA. Apparently, "capital market control" does not raise RoA. Our finding is consistent with Bezemer et al. (2015) who find that Dutch firms which enforce shareholder value orientation, end up with lower financial performance. But the interaction term "FoF-dummy $\times$ Listed res" has a significantly positive impact on RoA. To derive the overall effect of listing and foundation ownership, we add the coefficients $-0.21-0.030+0.096=0.045$ in regression (3). This sum is positive, but insignificant. Hence, listing and foundation ownership appear to have significantly negative effects on RoA, but together an insignificant positive effect. "Capital market control" may effectively counteract weaknesses in corporate governance of FoFs and vice versa. Hansmann and Thomsen (2013) also find that listing improves the financial performance of Danish FoFs.

The positive RoA-effect of mixed ownership is also confirmed in regression (4) which includes the voting share of the foundation and its square, instead of listing. The vote-effect is inversely u-shaped and clearly significant. Thus, financial performance tends to be better when a foundation acts together with other owners. This is in line with some studies of corporate governance which suggest that a blockholder improves financial performance, but a very strong owner lowers it (McConnell and Servaes 1990; Himmelberg et al. 1999). But the empirical evidence on ownership structure and financial performance is controversial (see the excellent overview in Demsetz and Villalonga 2001).

Apart from the foundation's voting share, the number of blockholders might affect financial performance (Van Essen et al. 2013). We define the free float in a FoF as the fraction of voting rights, neither held by the foundation nor by blockholders. A blockholder has at least $5 \%$ of the voting rights. In $3 / 4$ of the FoFs there is no free float, most FoFs are closely held firms. Neither free float nor the number of blockholders affects FoFs' RoA (not shown).

In regression (5) we test for the RoA-effect of labor intensity measured by PPM (= personnel expense / material expense). Its regression coefficient is about twice as high for matching firms relative to FoFs and strongly significant. This indicates that in particular matching firms might benefit from more labor intensity. Possibly, they outsource too much.

Financial performance of FoFs might decline with increasing age. The spirit of the founder may fade away, managers may care less. We measure the age of a FoF by the number of years since its setup as a FoF until 2013. We exclude the vote share as it strongly correlates with age. Using a quadratic function we find a significant, inverse u-shaped age effect on the RoA of FoFs (regression (6)). Thus, the RoA of FoFs would increase with age up to about 50 years and then decline. Moreover, 
within a FoF we do not observe aging effects on RoA between 2003 and 2012. FoFs apparently follow rather stable policies with stable RoAs ${ }^{13}$.

In the last regression in Table 11, we check the performance of FoFs with unlimited liability of the foundation. The interaction dummy "full liability $\times$ FoF" has a significantly negative impact on RoA. It suggests that, in contrast to the descriptive statistics in Table 2, full liability-FoFs earn lower RoAs. This may partly explain the setup of these FoFs. Full liability is more dangerous for partners if RoA is lower.

Our findings on financial performance of FoFs are inconsistent with those of Herrmann and Franke (2002) for Germany and those of Thomsen (1996), Thomsen and Rose (2004), and Thomsen and Hansmann (2013) for Denmark. Consistent with the null-hypothesis, they do not find weaker financial performance of FoFs relative to matching firms.

Our previous analysis with a linear control for risk indicates lower financial performance of FoFs. An alternative measure of financial performance is the Sharpe ratio SR:= average (annual RoA-12 months money market rate) / $\sigma$ (RoA). Its median is 1.06 for FoFs and 1.09 for matching firms; the difference is small and insignificant. In the OLS-regression:

$$
\begin{aligned}
\mathrm{SR}= & \mathrm{a}+\mathrm{b} \ln \text { average } \mathrm{OR}+\mathrm{c} \text { FoF-dummy }+\mathrm{d} \text { IFRS-dummy } \\
& + \text { industry dummies }+ \text { noise }
\end{aligned}
$$

all coefficients are insignificant. Also, when we look at subsets of FoFs and codetermined firms, coefficients remain insignificant. Hence, in contrast to our findings from the more sophisticated panel regression, financial performance, measured by the Sharpe ratio, is not inferior in FoFs and codetermined firms. The difference between both findings suggests that financial performance of FoFs and codetermined firms is somewhat weaker relative to matching firms, but that this effect is rather small. Hence Hypothesis 4 is weakly supported.

Summarizing, the separation of ownership and control associated with foundation ownership and codetermination has only small effects on financial performance. Privileged employee orientation in FoFs induces conservative instead of aggressive packages of employee benefits. The stakeholder model suggests that a move on the efficient frontier to a more favorable solution for employees should impair financial performance. But as the effect is small, FoFs likely operate on the efficient frontier of the stakeholder model if family firms do. As, in addition, FoFs appear to be financially sound and competitive, our findings do not indicate weak CG. Therefore we do not agree with $\mathrm{S} \& \mathrm{~V}$ who argue that $\mathrm{CG}$ is weak in the absence of powerful residual claimants. Possibly foundation managers, a special stakeholder group, act in the spirit of the founder to preserve the long run-existence of the firm and their reputation as supervisors. Thus, they may put pressure on the FoF-managers to safeguard profitability by good CG. Or managers and employees of the FoF themselves opt for good CG to preserve their jobs in the long run in a competitive environment.

\footnotetext{
13 This is also consistent with Franks et al. (2012) who find that family control persists in countries with inactive markets for corporate control. Germany might belong to these countries.
} 


\subsection{Robustness Checks}

To check our results, first, we address a potential survivorship bias. Our sample excludes firms which are merged, liquidated or strongly down- or upsized. Such events might be associated with strong changes in stakeholder orientation and business policy. Hence, these events might contaminate findings about the relation between stakeholder models and business policies. Therefore we exclude such events. Second, we report some robustness checks.

1. Firms can manage earnings through various channels. Arguably, the most important one is depreciation and amortization. Therefore we repeat the analysis of financial performance by replacing RoA =EBIT / TA by EBITDA / TA. EBITDA equals EBIT plus depreciation including amortization. The firm fixed effects are derived from the last regression in Table 10. An analysis of these effects as in Table 11 yields similar results (not shown).

2. The RoA-findings might differ for small and large FoFs. Therefore, we repeat the analysis for different size quartiles of FoFs. FoFs display a lower average RoA relative to matching firms for each size quartile.

3. The RoA-gap between FoFs and matching firms also exists in the crisis years 2008-2010.

4. More risky firms might pay out less to stabilize solvency. Therefore, we include $\sigma(\operatorname{RoA})$ in Table 9. Its coefficient is positive and weakly significant only if the payout ratio is restricted to the range $(-0.9 ; 0.9)$. This suggests that a firm's risk has a very small impact on its payout policy.

5. Somewhat tricky is the estimation of the Cobb-Douglas function. In Table 3 we report the results for a log-linear Cobb-Douglas function. We also run a panel regression for a quadratic function (translog production function) in personnel and material expense with separate slopes for matching firms and FoFs. We estimate four linear and four quadratic terms and two cross-terms. The coefficients of three linear terms are insignificant; all other coefficients are significant with varying sign (not shown). They are hard to interpret. Hence, the findings for the log-linear function need to be interpreted with caution.

6. We also check whether the number of matching firms has a strong impact on our findings. The results are quite similar if we move from 5 to 4 or 3 matching firms, but the findings change more if we move to 2 or 1 matching firm. This is expected because with 1 or 2 matching firms the specifics of these firms matter much more.

7. We repeat our analysis using a different matching procedure. Within the same industry we match a FoF with other firms by size and by age using nearest neighbour matching (Abadie et al. 2004). Age is the time span from the incorporation of the firm until 2013. The results (not shown) are quite similar to those obtained before. But the RoA-effects of listing and of full liability of the foundation are now insignificant.

8. Finally, we run a logistic regression to find strong predictors for a firm to be a FoF (see Table 12). 
Table 12 Logistic Regression

\begin{tabular}{lll}
\hline FoF & Coefficients & \\
\hline ln OR & - & $0.186^{* * *}$ \\
ln OR-growth & -1.754 & -1.890 \\
PPM & $0.063^{* * *}$ & $0.071^{* * *}$ \\
Leverage & $-1.563^{* * *}$ & $-1.737 * * *$ \\
RoA & $-3.508^{* *}$ & $-3.577 * *$ \\
$\sigma($ RoA) & $-7.836^{* *}$ & $-6.389 * *$ \\
HL $p$-value & 0.578 & 0.864 \\
\# of obs & 774 & 774 \\
\# of groups & 10 & 10 \\
\hline
\end{tabular}

This table shows the results of a logistic regression to find out which variables predict whether a firm is a FoF. For each time-dependent variable we take the average of its observations within the sampling period as a regressor. OR-growth is $\left(\mathrm{OR}_{\mathrm{t}} / \mathrm{OR}_{\mathrm{t}-1}\right)$. PPM is "Personnel expense / material expense". RoA is return on assets. $\sigma(\mathrm{RoA})$ is the standard deviation of the firm's return on assets within the sampling period. Industry dummies are included, but not shown. Significance is based on White standard errors correcting for heteroscedasticity. The Hosmer-Lemeshow (HL) $p$-value indicates the goodness of fit of the logistic regression. If it is less than $10 \%$, the model should be rejected as insignificant

$*, * *, * * *$ statistically significant at $10 \%, 5 \%, 1 \%$

An important predictor is the size "Operating revenue". In the first regression size is omitted, in the second it has a strongly significant, positive coefficient. The other predictors are the same in both regressions. The Hosmer-Lemeshow $p$-value which measures the goodness of fit of the model, strongly increases from about 58 to about $86 \%$. Annual growth of operating revenue tends to be smaller in FoFs, but it is insignificant. Strongly significant are "Personnel expense / material expense" (PPM) and leverage. FoFs are more labor intensive and less leveraged. Also, a lower RoA and a lower standard deviation $\sigma(\mathrm{RoA})$ raise the likelihood of a firm to be a FoF. The high Hosmer-Lemeshow $p$-value of $86 \%$ suggests that omitted variables are not a major problem in our analysis.

\section{Conclusion}

This paper contributes to the theory of corporate governance by analyzing the effects of foundation ownership and of codetermination on German firms. Foundations have no owners. In FoFs a foundation often is a blockholder, its managers supervise the firm. Since they are not residual claimants, CG of FoFs might be weak as suggested by Shleifer and Vishny (1997). Other stakeholders might be more powerful, in particular managers and employees of the FoF. Employees might strengthen their influence to benefit from higher wages, more jobs and more job security. Codetermination might have similar effects. Germany provides a unique opportunity to compare the effects of foundation ownership and codetermination.

We find privileged employee orientation in FoFs and codetermined firms relative to matching firms. But the package of employee benefits is conservative, not aggressive. FoFs and codetermined firms appear to be more labor intensive, they substitute labor for material, not for capital. Also they appear to take less risk and thereby 
safeguard the long term-existence of the firm and job security. But employees and board members do not earn higher income. Also annual hiring and firing of employees is hardly different, preserving flexibility of FoFs and codetermined firms. As we find similar effects for codetermined firms, our findings provide strong support for privileged employee orientation in FoFs.

Conservative packages of employee benefits explain why financial performance of FoFs is only slightly weaker relative to matching firms. Possibly strong competition in products and services markets and strict creditor policies leave little room for changes in CG which would substantially weaken financial performance. In codetermined firms also residual claimants may prevent such changes.

We find significant differences between FoFs and codetermined firms only in financing policy. While in our sample codetermination has no effect on financing policy, this policy is more conservative in FoFs, presumably due to a lack of powerful residual claimants. This stabilizes FoFs financially and also long term employment.

Ownership of charitable relative to family foundations has only limited effects. Labor intensity appears to be higher, given a charitable foundation, but financing policy and financial performance are about the same.

Regarding mixed ownership structures, the impact of the foundation's vote share on financial performance is inversely u-shaped. Surprisingly, listing of a firm at a stock exchange appears to impair performance. But if listing and foundation ownership coexist, then financial performance is not inferior. This suggests that foundation ownership and "capital market control" have weaknesses in CG which are overcome by synergy effects.

Our findings do not support the conclusion of $\mathrm{S} \& \mathrm{~V}$ that $\mathrm{CG}$ is weak in the absence of strong residual claimants. The small financial performance effects of foundation ownership suggest that FoFs operate on or close to the efficient frontier of the stakeholder model if family firms do. Thus, our findings challenge a mainstream of the CG literature.

Given various stakeholder approaches with varying stakeholder weights, there is a strong need for future research to better understand the effects of these variations on corporate governance and financial performance. Which variations safeguard/ endanger the long term existence of the firm? Which variations strengthen corporate social responsibility? More detailed studies of these mechanisms in different countries are required to develop a comprehensive theory of the relation between stakeholder approaches, CG and financial performance.

Acknowledgements We are very grateful for excellent and constructive comments to the associate editor Joerg Rocholl and an unknown reviewer, moreover to Steen Thomsen, Jens Jackwerth, William Judge, Colin Mayer, Ralf Brüggemann, Winfried Pohlmeier, Enrico Prinz, Holger Daske, Günther Gebhardt, Philipp Horsch, Marc Gerritzen, and the participants of the Workshop on the Nordic Corporate Governance Model at Copenhagen Business School in October 2013, the Inaugural Corporate Governance Conference at Copenhagen Business School in September 2015 and the Workshop on Foundations at the Technical University Munich in November 2015. 


\section{References}

Abadie, A., D. Drukker, J. Leber Herr, and G. Imbens. 2004. Implementing matching estimators for average treatment effects in stata. The Stata Journal 4:290-311.

Alchian, A. 1950. Uncertainty, evolution, and economic theory. Journal of Political Economy 58:211-221. Anderson, R., and D. Reeb. 2003. Founding-family ownership and firm performance: evidence from the S\&P 500. Journal of Finance 58:1301-1328.

Bau, M., and F. Chirico. 2014. Is the family an 'asset' or 'liability' for firm performance? The moderating role of environmental dynamism. Journal of Small Business Management 52:210-225.

Bezemer, P., E. Zajac, I. Naumovska, F. van den Bosch, and H. Volberda. 2015. Power and paradigms: the Dutch response to pressures for shareholder value. Corporate Governance: An International Review 23:60-75.

Bingham, J., W. Gibb Dyer Jr., I. Smith, and G. Adams. 2011. A stakeholder identity approach to corporate social performance in family firms. Journal of Business Ethics 99:565-585.

Boycko, M., A. Shleifer, and R. Vishny. 1995. Privatizing Russia. Cambridge: MIT Press.

Chen, J., M. Kacperczyk, and H. Ortiz-Molina. 2012. Do nonfinancial stakeholders affect the pricing of risky debt? Evidence from unionized workers. Review of Finance 16:347-383.

Coase, R. 1960. The problem of social cost. Journal of Law and Economics 3:1-44.

Core, J., W. Guay, and R. Verdi. 2005. Agency problems of excess endowment holdings in not-for-profit firms. Journal of Accounting \& Economics 41:307-333.

Croci, E., J. Doukas, and H. Gonenc. 2011. Family control and financing decisions. European Financial Management 17:860-897.

Demsetz, H., and B. Villalonga. 2001. Ownership structure and corporate performance. Journal of Corporate Finance 7:209-233.

Donaldson, T., and L. Preston. 1995. The stakeholder theory of the corporation: concepts, evidence, and implications. The Academy of Management Review 20:65-91.

Eisenhardt, K. 1989. Agency theory: an assessment and review. Academy of Management Review 14:57-74.

Van Essen, M., J. van Oosterhout, and P. Heugens. 2013. Competition and cooperation in corporate governance: the effects of labor institutions on blockholder effectiveness in 23 European countries. Organization Science 24:530-551.

Van Essen, M., V. Strike, M. Carney, and S. Sapp. 2015. The resilient family firm: stakeholder outcomes and institutional effects. Corporate Governance: An International Review 23:167-183.

Fama, E. 1980. Agency problems and the theory of the firm. Journal of Political Economy 88:288-307.

Fama, E., and M. Jensen. 1983. Separation of ownership and control. Journal of Law and Economics 26:310-325.

Fauver, L., and M. Fuerst. 2006. Does good corporate governance include employee representation? Evidence from German corporate boards. Journal of Financial Economics 82:673-710.

Fleschutz, K. 2007. Die Stiftung als Nachfolgeinstrument für Familienunternehmen - Handlungsempfehlungen für die Ausgestaltung und Überführung. Wiesbaden: Gabler.

Franks, J., and C. Mayer. 1997. Corporate ownership and control in the U.K., Germany, and France. Journal of Applied Corporate Finance 9:30-45.

Franks, J., C. Mayer, P. Volpin, and H. Wagner. 2012. The life cycle of family ownership: international evidence. Review of Financial Studies 25:1675-1712.

Furubotn, E. 1971. Toward a dynamic model of the yugoslav firm. The Canadian Journal of Economics 4:182-197.

Gorton, G., and F. Schmid. 2004. Capital, labor, and the firm: a study of German codetermination. Journal of the European Economic Association 2:863-905.

Götz, H., and F. Pach-Hanssenheimb. 2016. Handbuch der Stiftung, 2nd edn., Herne: NWB.

Grossman, S., and O. Hart. 1986. The costs and benefits of ownership: a theory of vertical and lateral integration. Journal of Political Economy 94:691-719.

Hall, P., and D. Soskice. 2001. Varieties of capitalism: the institutional foundations of comparative advantage. Oxford: Oxford University Press.

Hansmann, H., and S. Thomsen. 2013. Virtual ownership and managerial distance: the governance of industrial foundations. Copenhagen: Copenhagen Business School. Working paper.

Hausman, J., and W. Taylor. 1981. Panel data and unobservable individual effects. Econometrica 49:1377-1398.

Heath, J. 2014. Morality, competition, and the firm. Oxford: Oxford University Press.

Herrmann, M. 1996. Unternehmenskontrolle durch Stiftungen. Wiesbaden: Gabler. 
Herrmann, M., and G. Franke. 2002. Performance and policy of foundation-owned firms in Germany. European Financial Management 8:261-279.

Hill, C., and T. Jones. 1992. Stakeholder-agency theory. Journal of Management Studies 29:131-154.

Hillman, A., and G. Keim. 2001. Shareholder value, stakeholder management, and social issues. What's the bottom line? Strategic Management Journal 22:125-139.

Himmelberg, C., R. Hubbard, and D. Palia. 1999. Understanding the determinants of managerial ownership and the link between ownership and performance. Journal of Financial Economics 53:353-384.

Holmström, B. 1979. Moral hazard and observability. Bell Journal of Economics 10:74-91.

Hovakimian, A. 2004. The role of target leverage in security issues and repurchases. Journal of Business 77:1041-1072

Hung, M., and K. Subramanyam. 2007. Financial statement effects of adopting international accounting standards: the case of Germany. Review of Accounting Studies 12:623-657.

Institut für Demoskopie. 2012. Stiftungsunternehmen in Deutschland. Allensbach: Institut für Demoskopie.

Istaitieh, A., and J. Rodriguez-Fernandez. 2006. Factor-product markets and firm capital structure: a literature review. Review of Financial Economics 15:49-75.

Jensen, M. 1986. Agency costs of free cash flow, corporate finance, and takeovers. American Economic Review 76:323-329.

Jensen, M., and W. Meckling. 1979. Rights and production functions: an application to labor-managed firms and codetermination. Journal of Business 52:469-506.

Jirjahn, U. 2011. Ökonomische Wirkungen der Mitbestimmung in Deutschland: Ein Update. Schmollers Jahrbuch, Vol. 131, 3-57.

Jones, T., W. Felps, and G. Bigley. 2007. Ethical theory and stakeholder-related decisions: the role of stakeholder culture. Academy of Management Review 32:137-155.

Kallifatides, M., S. Nachemenson-Ekwall, and S. Sjöstrand. 2010. Corporate governance in modern financial capitalism. Cheltenham: Edwar Elgar.

Kochan, T., and S. Rubinstein. 2000. Toward a stakeholder theory of the firm: the saturn partnership. Organization Science 11:367-386.

Lewis, J., and D. Linzer. 2005. Estimating regression models in which the dependent variable is based on estimates. Journal of Political Analysis 13:345-364.

Lins, K., P. Volpin, and H. Wagner. 2013. Does family control matter? International evidence from the 2008-2009 financial crisis. Review of Financial Studies 26:2583-2619.

Magill, M., M. Quinzii, and J. Rochet. 2015. A theory of the stakeholder theory. Econometrica $83: 1685-1725$.

Mayer, C. 2013. Firm commitment: why the corporation is failing us and how to restore trust in it. Oxford: Oxford University Press.

McConnell, J., and H. Servaes. 1990. Additional evidence on equity ownership and corporate value. Journal of Financial Economics 27:595-612.

Myers, S. 1977. Determinants of corporate borrowing. Journal of Financial Economics 5:147-175.

Pepper, A., and J. Gore. 2015. Behavioral agency theory: new foundations for theorizing about executive compensation. Journal of Management 41:1045-1068.

Rajan, R., and L. Zingales. 1998. Power in the theory of the firm. Quarterly Journal of Economics 113:387-432.

Rebitzer, J., and L. Taylor. 2011. Extrinsic rewards and intrinsic motives: standard and behavioral approaches to agency and labor markets. Handbook of labor economics, Vol. 4, Part A, 701-772.

Shleifer, A., and R. Vishny. 1997. A survey of corporate governance. Journal of Finance 52:737-783.

Stiftung Familienunternehmen. 2017. Stiftung für Familienunternehmen in Deutschland und Europa, Daten, Fakten, Zahlen zur volkswirtschaftlichen Bedeutung von Familienunternehmen. München: Stiftung Familienunternehmen.

Strebulaev, I., and B. Yang. 2013. The mystery of zero-leverage firms. Journal of Financial Economics 109:1-23.

Thomsen, S. 1996. Foundation ownership and economic performance. Corporate Governance: An International Review 4:212-222.

Thomsen, S., and H. Hansmann. 2013. The performance of foundation-owned firms. Copenhagen: Business School. Working Paper.

Thomsen, S., and C. Rose. 2004. Foundation ownership and financial performance. European Journal of Law and Economics 18:343-364.

Tirole, J. 2001. Corporate governance. Econometrica 69:1-35.

Villalonga, B. 2000. Privatization and efficiency: differentiating ownership effects from political, organizational, and dynamic effects. Journal of Economic Behavior \& Organization 24:43-74. 